\title{
Europski putnici u Istri od XV. do XIX. stoljeća
}

\author{
Pregledni rad \\ Review article \\ UDK 910..4:821.163.42-992>:94(497.5-3 Istra)"14/18"
}

\begin{abstract}
U ovom je djelu analizirano šezdeset putopisa iz širokog razdoblja koje zahvaća dio srednjeg vijeka i novi vijek sve do početka proteklog stoljeća. Radovi su raznoliki: neki su putopisi pisani iz razonode, drugi da bi se čovjek jednoga dana mogao sjetiti vlastitih zapažanja i osobitosti s mladenačkog putovanja. Ima i putopisa koji su pisani iz vrlo praktičnih razloga, poput onih izvidničkih tekstova koje su uhode slale nalogodavcima. Bilo je i intelektualaca, znanstvenika koji su proučavali povijest kraja kroz koji su putovali. Bilo je ljubitelja starina, arhitekata, opata, etnologa i drugih znanstvenika. Većini je, međutim, Istra bila tek prolazna usputna stanica na putu prema Istoku, no ima i onih koji naš kraj posjećuju s nekom određenom namjerom. Analizirani su putopisi dio povijesti, plod raznolikih dojmova koji su stvorili sliku jednog kraja u određenom trenutku. Nisu nipošto manje vrijedni od drugih izvora, samo treba paziti na objektivnost.
\end{abstract}

Ključne riječi: putopis, Istra, novi vijek, Istok, hrvatska obala

$\mathrm{P}$

utopis vrlo često zahvaća povijest jednog kraja prepričavajući je ukratko. Stoga je nit koja dijeli putopis i kronike vrlo tanka. Prvi od druge preuzima odnos prema "istini". Treći dolazi dnevnik, jednostavnije djelo, čija je uloga samo bilježiti koji se događaj na koji dan zbio. Ivan Pederin ga naziva okvirom ispričanog vremena (Pederin 1991: 7). Putopis se piše s praktičnom svrhom. Pišu ga izvidnici koji njime izvješćuju vojni stožer i kralja, uhode koji šalju povjerljiva pisma visokoj ličnosti na dvoru ili pak kralju. Uhoda piše suhoparno i ciljano, ostaje anoniman; informira o vjeri žitelja neke zemlje, običajima, upravi (Pederin 1991: 10). Događalo se i da su uhode bile važne ličnosti, koje su iskorištavale vjerodostojnost položaja da dođu do informacija (Bertoša 1995: 348). Vojni stožeri drže te vrijedne papire u strogoj tajnosti. S namjerom da opišu stranu zemlju, pišu ih prirodoslovci poput Alexandera von Humboldta ili Charlesa Darwina, povjesničari umjetnosti kao Johann Joachim Winckelmann, Johann Wolfgang Goethe, Ferdinand Gergorovius, a u novije vrijeme diplomati i veleposlanici, poput Francisa Richarda Burtona, špijuni, pa naposljetku turistički novinari. Kako god bilo, u rečenicama putopisa se očituje osobnost pisca, izvjestitelja. Putopis je uvijek vrijedan. On ovjekovječuje pojedinu zemlju u određenom trenutku svoga doba, svoje povijesti. Putopis je književno djelo, jer obično ocrtava karakter zemlje, ne samo riječima, već i slikama, bakrorezima itd. Opisi, krajolici, spomenici, zemljovidi; sve te vrste djela nastaju s putopisom. Kasnije im se pridružuju slike, fotografije, fotoreportaže... (Pederin 1991: 7-8).

Putnici, lutalice, posjetitelji s određenim ciljem koji skreću s dobro poznatih i ugaženih putova da bi se upustili u potpuno neistražen svijet, prepun magije, popraćen lošim glasovima 
i gdje opasnosti svih vrsta vrebaju na svakom kutu. Vukovi, necivilizirana istočna plemena, medvjedi, lopovi i razbojnici lukavi kao lisice... Tako se u Europi pričalo o "balkanskim zemljama".

Istra je uvijek bila negdje u zavjetrini takvih "etiketiranja", nikada bura nemilih riječi nije ravno tukla u njena poluraspuštena jedra. Kras je označavao granicu između svjetla i tame, svijeta i mraka, općepoznatog i nedirnutog, što automatski izaziva strah. Međutim, iako pod upravom Mletačke Republike, nije ni ona uživala najpravednije dojmove europskog imaginarija. Bila je negativno konotirana, kao i hvaljena zbog svestrane prisutnosti svoje široke spomeničke kulture. Namjera nam je otkriti koga su putnici, putopisci, eminentne ličnosti Zapada upoznale i susrele u ovim krajevima kada su se naši preci borili sa sušama i požarima, ratovima i epidemijama, napuštenim područjima i novim, nekada prisilnim naseljavanjima, skromno živeći od poljoprivrede i stočarstva, a na obali od ribarstva.

Većina putnika, napose oni iz XVIII. i XIX. stoljeća, svoja djela po povratku u domovinu objelodanjuju i posvećuju monarhu, kojega hvale i poštuju.

Vrijedan spomena je srednjovjekovni putnik, otac talijanskog jezika i književnosti, pjesnik Dante Alighieri (1265-1321), za kojega ne znamo je li doista posjetio Istru ili ju samo spominje u čuvenoj rečenici “...sì com' a Pola, presso del Carnaro..." (Dante, Canto, VV 112117). Ugledna ličnost i autor Božanstvene komedije svakako zaslužuje svoje skromno mjesto na popisu istarskih putopisaca.

\section{Putnici putopisci u Istri u XV. stoljeću}

LUCHINO DI CAMPO, Viaggio del marchese Niccolò d'Este in Terrasanta (Olschki, Firenze 2011.)

1413.

Markiz je, u pratnji nekoliko plemića iz gradića Estea, krenuo prema Svetoj zemlji, prema Jaffi. Iz Venecije su dospjeli u Pulu, koja je već u ranom humanizmu bila poznata po svojim antičkim spolijama i sarkofazima rasutim po poljima. Markiza je pratio Luchino di Campo, koji je bio zadužen za pisanje putopisa.

MARIANO DA SIENA, Viaggio fatto al Santo Sepolcro (Pacini, Pisa 1991.) 1431.

U djelu hodočasnik spominje Pulu. Putnika je impresionirao broj sarkofaga koje je mogao vidjeti u gradu i okolici. Kako sam kaže, mnogi su sadržavali ljudske kosti. Također bilježi da su posjetili mnoge raskošne građevine, a vrhunac je bio amfiteatar vrlo sličan rimskom (Monzali - Šuran 2011: 94).

ROBERTO SANSEVERINO, Viaggio in Terra Santa... (Romagnoli, Bologna 1888.) 1458.

Sanseverino, hodočasnik na putu u Svetu zemlju, piše da su iz Venecije lako isplovili. Nakon što su svi na brodu večerali, zbog bonace, uz vesla, jasno im se pokazao Umag, grad u Istri, pa Poreč. Ovamo moraju pristati, piše Sanseverino, svi brodovi koji plove u Veneciju i unajmiti "pedota" (sic.), koji je specijaliziran da odveze brod do Venecije i da izbjegne opasne pličine usred lagune. To nameće državna odluka (Monzali - Šuran 2011: 95). 
WILLIAM WEY, Itineraries of William Wey, fellow of Eton College to Jerusalem, A. D. 1458 and A. D. 1462, and to Saint James of Compostella. A. D. 1456. 2 Vol. London, 1857 (J. B. Nichols and sons, London 1857.)

1458. i 1462.

William Wey bio je član koledža Eton netom nakon njegovog utemeljenja, a kralj Henrik VI. podario ga je obilnim davanjima koje je trebao potrošiti u podužim hodočašćima. Osamnaestog svibnja je isplovio iz Venecije i dva dana kasnije prošao kraj Poreča. Opći naziv kojim naziva prostranstvo zemalja i područje između Jadrana i srca Balkana mu je po antičkoj tradiciji Sclavonia (Levental 1989: 33-34).

Godine 1462. Wey ponovo plovi našim krajevima te spominje Poreč i rovinjsku Svetu Eufemiju, grad Pulu te Justinu. Nije jasno odnosi li se naziv Justina na neki toponim ili na Pulu i je li autor zamijenio Justinu s Iuliom (Colonia Iulia) "ili se radi o Kopru, na sjeverozapadnoj obali Istre, koji je u njegovo doba bio nazvan Justinopolom." Kaže da ovu zemlju zovu Istrom i da na njezinom području ima dvanaest biskupija pod mletačkom vlašću, iako znamo da ih je sveukupno u povijesti bilo šest (Levental 1989: 34).

\section{ALESSANDRO DI FILIPPO RINUCCINI, Sanctissimo peregrinaggio del Sancto Sepulcro} (Pacini, Pisa 1993.)

1474.

"Pod slabim su vjetrom jeruzalemski poklonici krenuli iz Venecije u ponoć i jakom bonacom lagano plovili u smjeru Poreča". U tom kontekstu saznajemo o ubojstvu koje se dogodilo, a koje je Rinuccina iznenadilo. Nije bio toliko dirnut samim činom već ravnodušnošću nadležnih vlasti koje nisu ništa poduzele, čime su pridonosile bezvlađu. Na sreću, nisu svi putnici nazočili sličnim epizodama pa ima onih koji hvale Istru i njezino ljubazno i veselo žiteljstvo (Monzali-Šuran 2011: 95-96).

\section{Putnici putopisci u Istri u XVI. stoljeću}

RICHARD GILFORD, The Pylgrimage of Sir Richard Guylforde to the Holy Land (Henry Ellis, Richard Pynson, Richard Guylford, Camden Society, London 1851.) 1506.

Gilford je bio visoki dostojanstvenik i osobni savjetnik kralja Henrika VII. Odlučio se za hodočašće u Svetu zemlju i u svibnju 1506. nalazio se u Veneciji. U Poreč je stigao nakon gotovo dvodnevne plovidbe. Englez spominje da je u ovom gradu grob sv. Mauricija (misli na porečkog mučenika sv. Maura). Ploveći duž obale rutom od trideset milja, koja ga je odvajala od Pule, kaže da su prošli pored obala Sklavonije i Istre. Nadalje navodi da Pula ima dobru luku u koju pristaje više brodova i galija nego u Poreču. Na povratku prolaze kraj Pule, gdje razgledavaju Rolandovu tvrđavu za koju kaže da je izgrađena po uzoru na rimski Kolosej. Putopisac je ovom prilikom nešto pomiješao. Rolandov toranj ili palača jesu postojali u Puli, no taj se naziv sigurno nikada nije odnosio na Arenu. U Poreču su bili na nedjeljnoj misi, a zaustavili su se i u Novigradu (Levental 1989: 36-38).

RICHARD TORKINGTON, Ye Oldest Diarie of Englysshe Travell: being the hitherto unpublished narrative of the pilgrimage of Sir Richard Torkington to Jerusalem in 1517. (Field \& Tuer, London 1884.) 
1517.

U XVI. stoljeću sir Richard Torkington putuje iz Engleske u poklonstvo Svetoj zemlji. Njegov je putopis gotovo prijepis Gilfordovog. Bio je u Rovinju, odslušao misu, prenoćio na brodu, prošao kraj Pule. Torkingtona najviše zanimaju biblijska povijest, topografija svetih mjesta te vino (Levental 1989: 40-41).

COLANTONIO CARMIGNANO, Operette (Per mastro Gilliberto Nehou francese in le case de Santo Nicola, Bari 1535.)

1518.

Carmignanu je 1518. povjerena zadaća da opjeva u stihovima putovanje plemkinje Isabelle d’Aragona Sforza iz Barija u Krakov. Na putu su preplovili Kvarner, dotaknuli otok Krk, a od Rijeke nadalje put su nastavili kopnom. U Rijeci su se zabavljali devet dana da zaborave muke mora (Monzali - Šuran 2011., str. 87-90).

SEBASTIANO SERLIO, Tutte l'opere d'architettura et prospetiva di Sebastiano Serlio (Giacomo de' Franceschi, Venecija 1619.)

1536.

Sebastiano Serlio (1475. - 1554.) posjetio je Pulu 1536. godine. Dragocjeni su nam njegovi opisi i nacrti, iako nisu detaljni kao Palladijevi. Njegovo djelo predstavlja najstarije prikaze antičkih spomenika Pule. Valja naglasiti da je njegovo djelo o antičkim spomenicima odigralo veliku ulogu na generacije arhitekata (Kečkemet 1969: 553) i arheologa. O važnosti njegova djela govori podatak da je knjiga prevedena na strane jezike (Kudiš 1994: 96). "Tutte l'opere d'architettura di Sebastiano Serlio", u drugom izdanju "Tutte l'opere d'architettura et prospetiva di Sebastiano Serlio", doživjela veliki broj izdanja (venecijansko, flamansko, francusko, londonsko) i u svakome autor donosi opise i ilustracije antičkih spomenika Pule. Bila je to odlična reklama našem gradu, koji je ovim putem populariziran u čitavoj Europi (Kečkemet 1969: 554).

Treća knjiga prikazuje pulske spomenike i naslovljena je: “Treća knjiga Sebastiana Serlija, Bolonjca, u kojoj se objašnjavaju i opisuju starine Rima i ostale koje su u Italiji i izvan Italije". ${ }^{1}$ Nakon opisa rimskih spomenika, čitamo da u Puli, dalmatinskom gradu na moru, postoji veći dio kazališta, gdje se domišljati arhitekt naslonio na brdo, dobivši tako podlogu za dio sjedišta. U prizemlju je osmislio parter i pozornicu (orkestar i scenu) i ostale dijelove koje takva građevina mora imati. Ima svakojakih stupova koji su izrađeni korintskim stilom. Cijelo je kazalište, uostalom, i u unutarnjoj i na vanjskoj strani rezultat korištenja korintskog graditeljskog stila (Kečkemet 1969: 554).

www.virtual.unal.edu.co/cursos/sedes/manizales/4020061/descargas/d_serlio.pdf (7. listopada 2011.). 
PIETRO COPPO, Del sito del Istria (Bindoni i Pasini, Venecija 1540.)

1540.

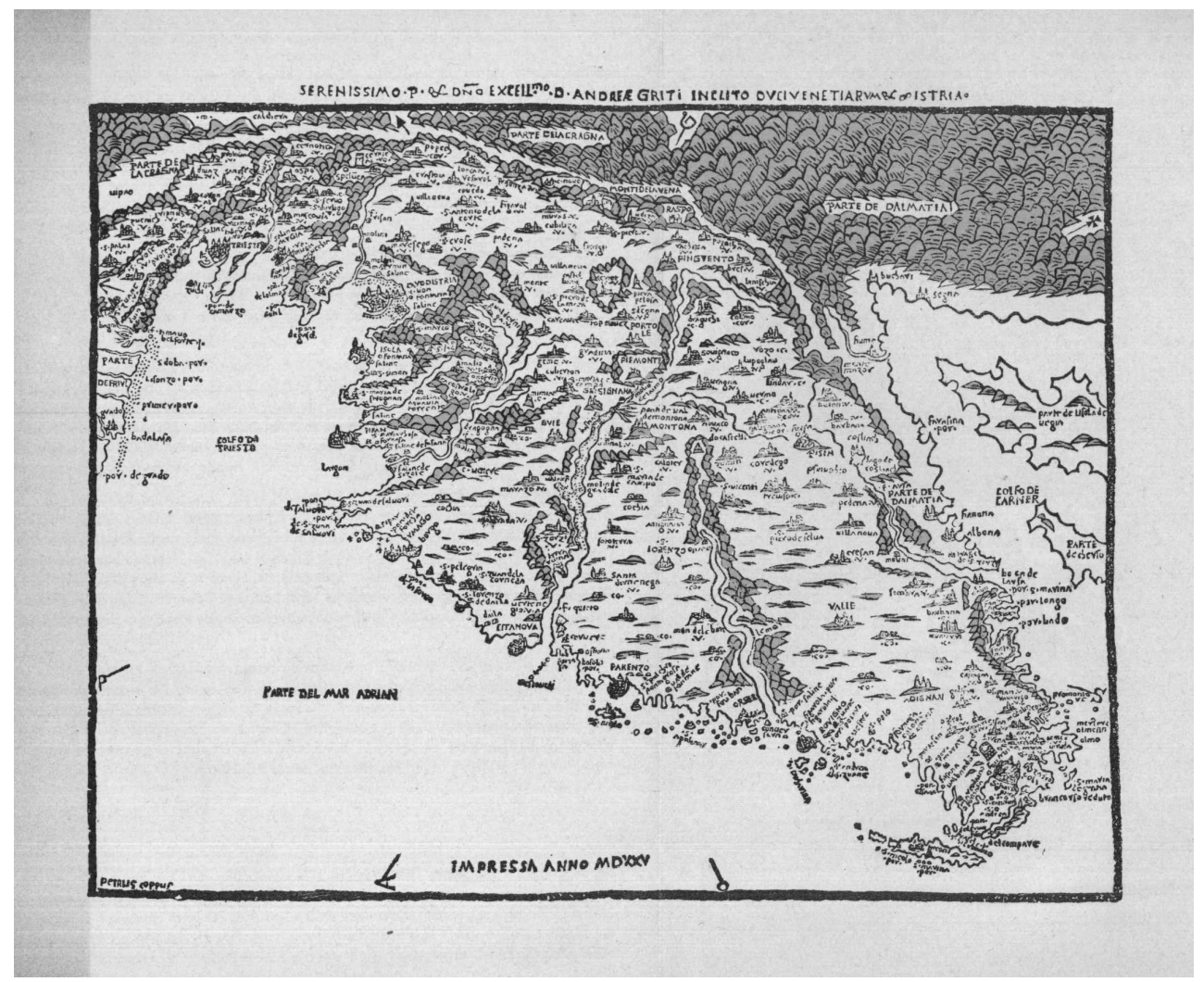

SI. 1: Coppova karta Istre iz 1525.

http://www.mondogeo.it/Immagini/Mappe/Istria\%20in\%20xilografia\%20del\%201525\%20-\%20Pietro\%20Di\%20 Coppo.jpg (23.10.2013.)

U traktatu "Del sito del Istria" autor iznosi svoja zapažanja te stručno mišljenje o stanju na terenu na koja nailazi. Radi se o prvom zemljopisom opisu Istre koji zahvaća gradove, naselja, otoke, luke i rijeke. 
ANDREA PALLADIO, I quattro libri dell'architettura (Dominico de' Franceschi, Venecija 1570.) 1545.-1550.

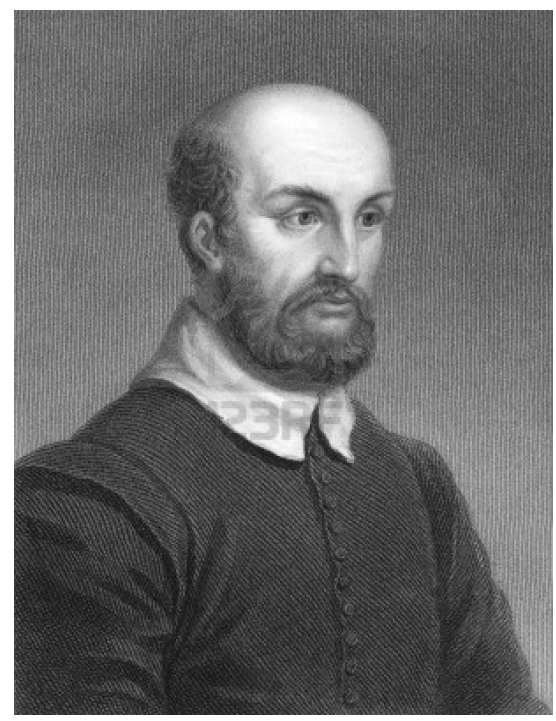

SI. 2. Andrea Palladio, portret

http://www.123rf.com/photo_8520564_andrea-palladio-1508-1580-on-engraving-from-the-1800s-italianrenaissance-architect-engraved-by-r-wo.html (23.10.2013.)

Andrea Palladio (1508. - 1580.) boravio je u Puli od 1545. do 1550. Bio je poznati mletački renesansni arhitekt i teoretičar. S obzirom na to da je predmet njegova zanimanja bilo povijesno-kulturno nasljeđe, usredotočio se na arhitektonsku stranu pulskih spomenika. U njegovom tekstu često ćemo naići na mjere, dužine, a njegov vokabular obiluje stopama, palcima, prostilima, stupovima, sistilima, podnicama, pročeljima, arhitravima, itd. Palladijevi nacrti imaju izvanredan dokumentarni značaj. Nastali su u Puli u XVI. stoljeću, a nalaze se u odjelu crteža Kraljevskog instituta britanskih arhitekata u Londonu (Kečkemet 1969: 549; 550-551).

Palladio je na temelju tih crteža iznio svoju teoriju o arhitekturi u poznatom djelu "I quattro libri dell'architettura" kojim su se u u renesansi koristili svi poznati arhitekti. Prvo izdanje tog djela objavljeno je trideset godina prije kraja XVI. stoljeća pod naslovom:

I QVATTRO LIBRI DELL'ARCHITETTURA, di Andrea Palladio, Nè quali, dopo un breue trattato de' cinque ordini, \& di quelli auertimenti, che sono più necessarij nel fabricare;

SI TRATTA DELLE CASE PRIVATE, delle Vie, de i Ponti, delle Piazze, de i Xiti, e de Tempij, CON PRIVILEGI. IN VENETIA, appresso Dominico de' Franceschi 1570.

Inigo Jones u engleskom izdanju Palladijeva djela 1742. nadopunjuje i ispravlja njegove nacrte pulskih hramova (Inigo Jones, The Architecture of A. Palladio in four books...With notes and remarks of Inigo Jones. London MDCCXLII). 
JOHN LOCKE, The voyage of M. John Locke to Jerusalem - U: Richard Hakluyt, The principal navigations, voyages, traffiques and discoveries of the English nation, made by Sea or overland, to the remote and farthest distant quartersof the earth, at any time within the compasse of these 1600 years: divided into three severall volumes according to the positions of the regions whereunto they were directed ..., Vol. II. (George Bishop, Ralph Newberie, Robert Barker, London 1885.)

1553.

John Locke bio je engleski putnik iz XVI. stoljeća koji je odlučio otputovati u Jeruzalem. U Rovinju je posjetio crkvu svete Eufemije, gdje se poklonio tijelu svetice. Isplovivši, kaže da je ugledao ankonske planine i brda Dalmacije, odnosno Sklavonije (Sclavonia). Usidrili su se kod Rovinja, gdje svaki brod mora obvezatno uzeti pilota do Venecije. Kaže da su po ljeti svi piloti u Rovinju, a zimi borave u Poreču (Levental 1989: 42-44).

GIOVANNI FRANCESCO CAMOTIA, (Camotio, Camocio) Isole famose, porti, fortezze, terre marittime della Repubblica di Venezia ed altri principi cristiani (Libraria del segno di S. Marco, Venecija 1574.)

1572.

Giovanni Francesco Camotia ili Camocio po zanimanju je bio kartograf i izdavač. Njegove su se knjige tiskale s potpisom apresso/apud G. F. Camotio cum privileggio, a izdavačka djelatnost je imala oznaku al segno della pyramide. Izradio je bakrorez koji je nazvao "Isole famose, porti, fortezze, terre marittime della Repubblica di Venezia ed altri principi cristiani", objelodanjen u Veneciji 1571.-1572. Pula je površno prikazana s bližom okolicom. Slikovito je opasuju gradske zidine, a natpis Coliseo antico stoji iza amfiteatra, monumentalnih obilježja, no predaleko od mora. Oslikan je na četiri kata. Izvan gradskih zidina, Camotia ucrtava hrpu ruševina koje naziva Ruine Antiche. Među njima se ističe slavoluk (Kečkemet 1969: 555).

GEORG BRAUN, Beschreibung und Contrafactur der vornehmsten Städte der Welt (Gottfried von Kempen, Köln 1574.)

1574.

Godine 1574. izdavač Gottfried von Kempen tiska u Kölnu zbirku bakroreza pod naslovom "Beschreibung und Contrefactur der vornehmsten Städte der Welt". U zbirci je svoje mjesto našla i gravura Poreča (Pederin 1991: 20).

HENRY AUSTELL, The voyage of Master Henry Austell by Venice and thence to Ragusa over land, and so to Constantinopole: and from thence by Moldavia, Polonia, Silesia and Germanie to Hamburg, \& c. - U: Richard Hakluyt, The principal navigations, voyages, traffiques and discoveries of the English nation, made by Sea or overland, to the remote and farthest distant quartersof the earth, at any time within the compasse of these 1600 years: divided into three severall volumes according to the positions of the regions whereunto they were directed ..., Vol. II. (George Bishop, Ralph Newberie, Robert Barker, London 1885.)

1585.

Bilješke kapetana Henryja Austella uzbuđuju sve one koje zanima povijest putovanja. On se, naime, prije četiristo godina usudio proputovati do Carigrada ne mareći za granice, kvalitetu putova, putovanja morem ili kopnom. Njegov stil i putopis više sliče dnevniku. Autor bilježi sva mjesta pored kojih prolazi. Opisi su lišeni bilo kakvih emocija i doživljaja, što bi takva putovanja sama po sebi trebala potaknuti. Dana 2. kolovoza 1585. kotorska ga je 
fregata odvela iz Venecije u istarski Novigrad. Četvrtog je dana bio u Poreču, gdje navodi da je proveo noć u biskupskom kaštelu. Možda se ovdje radi o nekadašnjoj biskupskoj palači ili kaštelu u Vrsaru. Petog dana prošli su pored Rovinja, a malo dalje susreću tri mletačke galije. Pulu su vidjeli izdaleka, a zatim su preplovili zaljev koji dijeli Istru od Dalmacije (Levental 1989: 45-46).

HARRIE CAVENDISH / FOX, Mr. Harrie Cavendish his Journey to and from Constantinopole 1589 by Fox, his Servan (Royal Historical Society, London 1940.)

1589.

Harrie Cavendish spada u imućnije putnike koji su posjetili naše krajeve. S njim je putovao sluga koji je opisao pustolovinu. Sluga Fox na samom početku njegovog rukopisa donosi tablični pregled noćenja na temelju kojeg saznajemo u kakvim se uvjetima spavalo. Tako je npr. 25. svibnja Fox spavao u kokošinjcu, idućeg dana na klupi, dok je 27. svibnja spavao na kolima kraj seljačke kuće. Sljedeće noći dobio je poveću hrpu sijena na kojoj je spavao "poput kralja". Dana 30. svibnja spavao je na podu u kući jednog seljaka (Levental 1989: 48).

Kako Cavendishu glavni cilj nije bila Istra već Carigrad, u Istri se nije zadržao nego samo spominje Rovinj i svetog Jerolima, gdje su se snabdjeli pitkom vodom. Vrlo su zanimljiva Foxova opća zapažanja, gdje ima podataka o životu posjećenih krajeva, zemljoradničkih navika, morfologije krajolika, vjere i drugoga (Levental 1989: 48-52).

FYNES MORYSON, An Itinerary (by Fynes Moryson, Gent.), containing his ten years Travels through the twelve Dominions of Germany, Bohmerland, Switzerland, Netherland, Denmark, Poland, England, Scotland, and Ireland. Divided in three parts (J. MacLehose, Glasgow 1908.)

1597.

Braća Fynes i Henry Moryson kreću na put 1595.

Autor se otvoreno žali na uskoke. Godine 1597. plovio je Kvarnerom, za koji piše da je opasan te da u njemu mnoga plovila stradaju. Dodao je jednu od uobičajenih mletačkih psovki: "Proklet bio Kvarner koji te pustio da prođeš". Možda se opasnost kojom opisuju Kvarner više odnosila na uskočke napade nego na opasnost same plovidbe. Iz njegova teksta saznajemo da su u ponedjeljak, 25. travnja, jedrili uz obale Istre, a idućeg su dana pristali iza Pule, grada koji je onda bio u ruševinama. Dana 27. travnja ušli su u rovinjsku luku, koja je po njihovim riječima pripadala Presvijetloj Republici. Kaže da ovdje putnici obično uzimaju pilota, u prvom redu radi sigurnosti plovidbe, a potom jer je Rovinj nekada uživao povlastice. Moryson se začudio kada je uvidio da su većina stanovnika Rovinja bili bogalji. Nije doznao uzrok, ali pretpostavlja da se radi o pretjeranoj konzumaciji vina (Levental 1989: 53-55, 5658).

GIUSEPPE ROSACCIO i MARCO SADELER, Viaggio da Venetia a Costantinopoli Per Marre, $e$ per Terra, et insieme quello di Terra Santa cioe Citta, Castelli, Porti, Golfi, Isole, Monti, Fiumi e Mari, Opera utile, a Mercanti Marinai, et a studiosi di Geografia (Giacomo Franco, Venecija 1598.)

1598.

Otkako je Venecija postala pomorska sila, osjećala se velika potreba i interes za boljim poznavanjem prostora na istočnom Jadranu i neizbježni plovidbeni put po kojemu su svakodnevno plovili mletački trgovci, zbog čega su priručnici bili jako cijenjeni. Tomu je pridonio pravnik, liječnik, humanist i kartograf Giuseppe Rosaccio, čiji "Viaggio da Venetia 
a Costantinopoli" sadrži korisne podatke o pojedinim obalama, otocima i lukama Jadrana (Pavić 2002: 153-154).

VINCENZO SCAMOZZI, L'Idea della Architettura universale di Vincenzo Scamozzi Architetto Veneto. Diuisa in X libri. In Venetia MDCXV (Per Giorgio Valentino, Venecija 1615.)

XVI.-XVII. stoljeće

Vincenzo Scamozzi rodio se u Vicenzi 1552., gdje je i umro 1616. U posljednjoj godini života izdao je djelo "L'Idea della Architettura universale di Vincenzo Scamozzi Architetto Veneto. Diuisa in X libri. In Venetia MDCXV", u kojemu spominje Pulu i slavoluk. U francuskom izdanju iz Pariza 1685. o njima je riječ na 9., odnosno 114. stranici (Pavić 2002: 153-154). Arhitekt je, dok je bio u službi Venecije, najvjerojatnije posjetio Pulu i njezine spomenike, no mogao ih je upoznati i iz izvora, budući da je jedno vrijeme posjedovao Palladijeve crteže, koji su poslije prešli u Burlingtonovu kolekciju.

INIGO JONES, The Architecture of A. Palladio in four books... With notes and remarks of Inigo Jones. London MDCCXLII (Ward, Birt, Browne, Davis, Osborne, Millar, London 1742.)

XVI.-XVII. stoljeće

Inigo Jones bio je londonski arhitekt koji je živio od 1573. do 1652. godine. Također je bio dobar poznavatelj pulskih spomenika, jer je komentirao i ispravio pojedine Palladijeve nacrte. Njegove intervencije najviše se odnose na korekciju mjera, odnosno dimenzija, što nije mogao učiniti bez boravka u Puli. Knjiga u kojoj nalazimo Jonesove intervencije nosi naslov: "The Architecture of A. Palladio in four books...With notes and remarks of Inigo Jones. London MDCCXLII". U njoj autor donosi tablice tlocrta, bočne strane, pročelja i detalje pulskog hrama (Kečkemet 1969: 556).

\section{Putnici putopisci u Istri u XVII. stoljeću}

WILLIAM LITHGOW, The Totall Discourse of the rare Adventures and poinefull Peregrinations of long nineteene years Travailes from Scotland to the most famous Kingdomes in Europe, Asia and Affrica (J. MacLehose, Glasgow 1906.)

1609.

William Lithgow bio je visoko obrazovan Škot koji je imao neodoljivu strast i volju za putovanjima.

Krenuvši na put iz Venecije, brod je zahvatilo jako nevrijeme. Puhali su jugo i zapadnjak, kapetan nije bio spretan u upravljanju brodom, a nije ni posjedovao kompas. Bili su prisiljeni potražiti zaklon u luci u Poreču, o kojem autor iznosi povijesne, bolje rečeno mitološke priče i zanimljive podatke o regiji. Razgledao je ruševine Justinopolisa, današnjeg Kopra. Bilježi da je tada izgubio na važnosti i da su glavni gradovi Istre Poreč, Umag, Pula i Rovinj. Na putu prema jugu prošli su otočje Brijuni, gdje se, po njegovim riječima, vadi izvrstan mramor, nazvan istarskim, koji krasi mletačke palače. Nastavlja da su oko podne ugledali pulsku luku koja može primiti male brodove. Iznad nje uzdiže se Mount Caldonia, pri čemu je autor možda mislio na Ćićariju, koja se na talijanskom zove "Catena dei Monti Caldiera". Pulska luka nije osobito prometna zbog zaraženog, malaričnog zraka. ${ }^{2}$ Autor zatim posjećuje Orlandovu utvrdu, slavoluk i ostatke amfiteatra. Bilježi da je Plinije Pulu nazvao Julia Pietas (Levental 1989: 66-67, 70-71).

Problem će riješiti tek Robert Koch početkom XX. stoljeća (Rudelić 1977). 
GEORGE SANDYS, Relation of a lourney begun An. Dom. 1610. Foure Bookes Containing a Description of the Turkish Empire, of Aegypt, of the Holy Land, of the Remote parts of Italy, and Islands adioyning (Robert Allot, London 1627.)

1610.

George Sandys otišao je iz Francuske nakon ubojstva kralja Henrika IV., a s obzirom da je bio zasićen opisima francuskih i talijanskih gradova, njegov dnevnik počinje u Veneciji, odakle isplovljava 2. kolovoza 1610. na malom brodu zvanom "London", na kojem će nastati tekstovi o mjestima koje je posjećivao, ponajprije Istre (Levental 1989: 73-74).

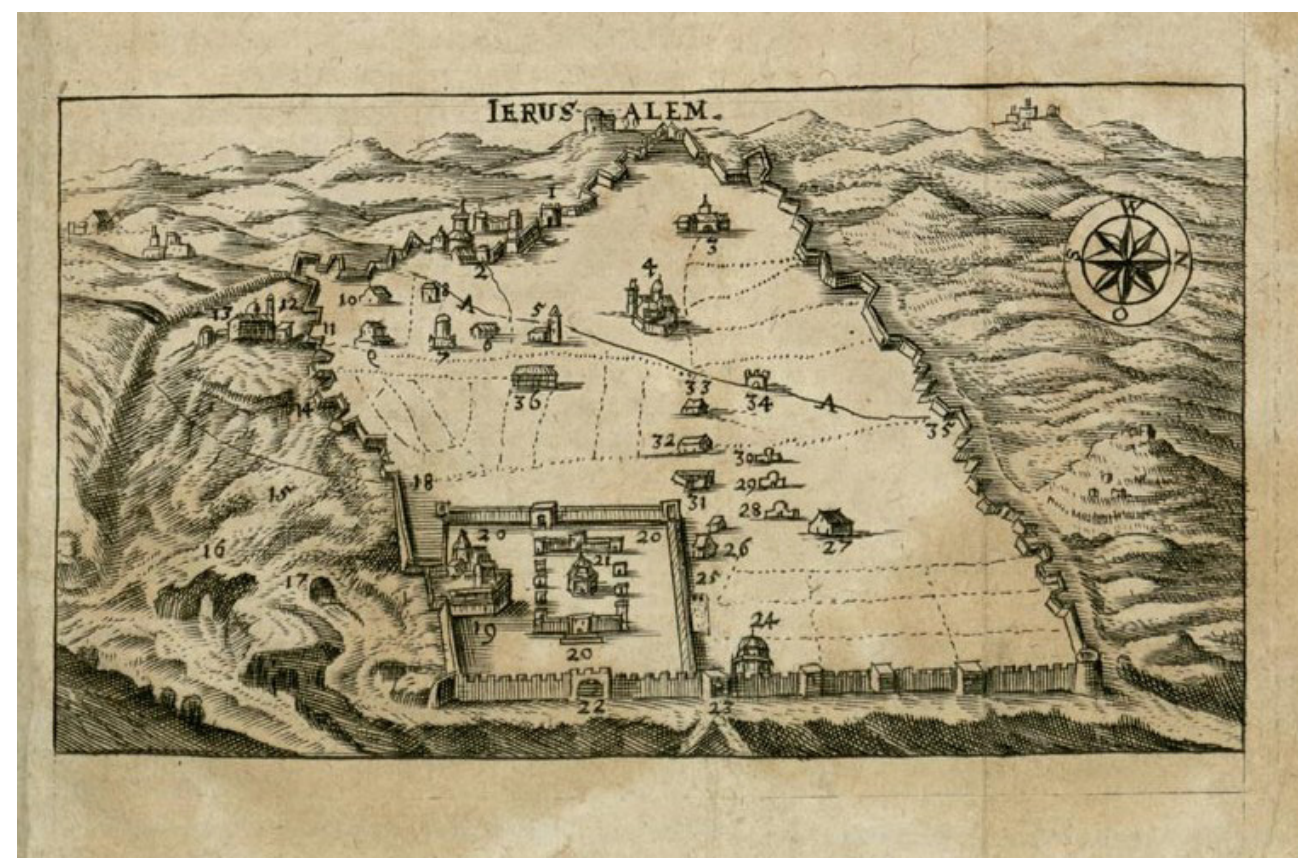

SI. 3: Veduta Jeruzalema

http://jnul.huji.ac.il/dl/maps/jer/images/jer245/Jer245_b.jpg (23.10.2013.)

PETER MUNDY, The Travels of Peter Mundy in Europe and Asia, 1608-1667. Vol. I. Travels in Europe, 1608-1628. Cambridge, 1907. (Cambridge: University Press, 1907.) 1620.

Paul Pindar, nakon što je više od osam godina službovao kao engleski veleposlanik u Carigradu, 1620. uz brojnu pratnju vratio se u Englesku. Njemu su se pridružili mnogi putnici koji su htjeli što sigurnije stići do kućnog praga. Među njima je bio i Peter Mundy, koji je, iskoristivši priliku, ostavio zapise o istarskoj obali kraj koje su prošli (Levental 1989: 73 i 84).

HENRY BLOUNT, A Voyage into the Levant. A Briefe Relation of a lourney lately performed by Master H. B. Gentleman, from England by the way of Venice, into Dalmatia, Sclavonia, Bosnah, Hungary, Macedonia, Thessaly, Thrace, Rhodes and Egypt, unto Gran Cairo: With particular observations concerning the moderne condition of the Turkes, and other people under that Empire (Andrew Crooke, London 1636.) 
1634.

Henry Blunt bio je svojevrsni antropolog. Na svojim putovanjima samo se usput zanimao za prirodne ljepote i povijesne spomenike. Blunt zapravo putuje da upozna Osmansko Carstvo, koje se u njegovo doba naglo uzdignulo, toliko da je i Zapadu predstavljalo ozbiljnu prijetnju. Na putovanju prošao je uz istarsku obalu (Levental 1989: 95-96, 86-87).

JACOB SPON \& GEORGE WHELER, Voyage d'italie, de Dalmatie, de Grece, et du Levant, Fait aux Années 1675. Et 1676. Par Jacob Spon Docteur Medecin Aggrege A Lyon Et George Wheler Gentil-Homme Anglois. Tome I. (Henry \& Theodore Boom, Amsterdam 1679.)

1675.-1676.

Jacob Spon, liječnik i sakupljač starina iz Lyona, i George Wheler, engleski svećenik, prirodoslovac i putopisac, rodom iz Brede u Nizozemskoj, sreli su se u Rimu. Zajedno su 1675. iz Venecije krenuli na dvogodišnji put. Na putu su prošli duž naše obale dotaknuvši se glavnih istarskih gradova. U djelu "Voyage d'italie, de Dalmatie, de Grece, et du Levant, Fait aux Années 1675. et 1676. Par Jacob Spon Docteur Medecin Aggrege A Lyon Et George Wheler Gentil-Homme Anglois. Tome I. A Amsterdam, Chez Henry \& Theodore Boom, MDCLXXIX"3 nalaze se dva prikaza (bakrorez pročelja hrama Rome i Augusta kojemu ne vidimo temelje i bakrorez pročelja slavoluka s antičkim natpisima s obje strane) i zanimljiv opis (Kečkemet 1969: 556). Djelo sadrži, osim putopisnih opisa, i nešto epigrafije, u duhu francuskog klasicizma.

Spon je zaljubljenik u starine, koje kod nas, gdje putuje s klasicima pod rukom (Pederin 1991: 21), nalazi u izobilju. Prva knjiga nosi naslov "Put po Provenci i Italiji”, a druga "Put po Dalmaciji, Zakintu i drugim mletačkim otocima do Carigrada".

GEORGE WHELER / JACOB SPON, A Journey into Greece by George Wheler Esq; in Company of Dr Spon of Lyons. In Six Books (William Cademan, Robert Kettlewell, and Awnsham Churchill, London 1682.)

1675.

George Wheler je u svom izvješću napisao zapažanja s putovanja u Grčku. ${ }^{4}$ Zemlju je opisao kao nekadašnju gospodaricu civilizacije koja je izgubila svaki sjaj. Na putu ga je pratio dr. Spon, također zaljubljenik u starine, koji je prvi izdao putopis na francuskom jeziku (Krmpotić 1997: 153). Englez je dvije godine proučavao mjesta u Francuskoj i Italiji pa se odlučio na promjenu i okrenuo na Istok. Za suputnika izabrao je Spona, obzirnog čovjeka, liječnika, od kojega je saznao da je iz Venecije trebao krenuti na put, put Carigrada, jedan bailo (mletački poslanik) (Levental 1989: 154-156).

FRANCIS VERNON, Mr. Francis Vernons Letter, written to the Publisher, Januar. Loth 1675/6, giving a short account of some of his Observations in his Travels from Venice through Istria, Dalmatia, Greece, and the Archipelago to Smyrna, where this Letter was written. In:

\footnotetext{
U Sveučilišnoj knjižnici u Puli čuva se njemački prijevod iste knjige: "Italiänische/Dalmatische/Griechische und Orientalische Reise=Beschreibung. Worinn Allerhand merkwürdig/vormals in Europa unbekannte/ Antiquitäten/enthalten/Welche Jacob Spon/Med. Doctor, und Georgius Wheler, Englischer von Adel/Als sie obbenannte Lande/im Jahr 1675. und 1676. durchreiset/fleissig zusammen getragen/und der Welt/ zu nüsslicher Nachricht/in der Druk befördert. Erste Theil. Anjetso aber aus dem franzözischen in Deutsche übersetzt durch ? ? Collegii Christiani-Ernestini Prof. Publ. Nürnberg/In Verlegung Johann Hofmanns/Buch=und Kunsthändlers. Daselbst gedruckt bei AndreasKnockenfeel. Wittib Im Jahr Christi M. DC. XC." U originalnom izdanju, gravura Augustova hrama se nalazi na str. 62., Slavoluk i natpisi su na str. 63.

$4 \quad$ U predgovoru se raspravlja na tu temu s doktorom Sponom, koji je prije njega već objavio na francuskom jeziku zapažanja sa zajedničkog putovanja u Grčku.
} 
Philosophical Transactions, Vo. XI. Number 124, April 24. 1676 (Royal Society, London 1676.) 1676.

Vernon je putovao od Venecije, Istrom i Dalmacijom do Smirne (Izmira) u Turskoj. Iz grada u današnjoj Italiji krenuo je na galiji na kojoj je putovao i mletački ambasador. Na putu su pristajali u većini važnijih gradova. U Puli su vidjeli amfiteatar, za koji kaže da je sačuvan u cijelosti i s dva reda toskanskih stupova. Osim amfiteatra, pogledali su Augustov hram i Slavoluk (Levantal 1898: 168).

VINCENZO MARIA CORONELLI, Ristretto della DALMAZIA Diuisa né suoi Contadi, gia presentata ALLA SERENISSIMA REPUBLICA DI VENEZIA, et c. / Dal P. Maestro Coronelli M. C. Cosmografo Publico... / ISOLE DELLA DALMATIA Diuise Ne Suoi Contadi, Parte Occidentale. Miglia d'Italia 30 (= $95 \mathrm{~mm}$ ). - Venetia: Vincenzo Maria Coronelli (Vincenzo Maria Coronelli, Venecija 1697.)

1697.

Vincenzo Maria Coronelli je kartograf koji je veći dio svoga života proveo u Veneciji. $\mathrm{Na}$ jednoj od njegovih precizno izrađenih karata prikazana je i Istra. Na karti se spominju istarsko more, Kvarner i latinska imena nekih istarskih gradova. ${ }^{5}$ Mletačka Republika poticala je nastajanje takvih djela kako bi sama sebi olakšala putovanja i osvajanja na Mediteranu. Takve su karte bile dragocjene i u ratu.

\section{Putnici putopisci u Istri u XVIII. stoljeću}

SIMON CLEMENT, A Journal of my travails into the Lower Hungary, Sclavonia, Croatia, Friuli, Carniola and Stiria in the year 1715 (Levental 1989: 174-175)

1715.

Simon Clement putuje sjeveroistočno od naših krajeva, ali će se njegova skitanja dotaknuti i sjeverne granice Istre. Njegov prolazak kroz naše zemlje nije previše jasan. Najviše ga zanimaju kakvoća zemlje, trgovina i poljoprivreda. Poseban naglasak stavlja na zapažanje o vinogradarstvu i o vinima. Ne izostavlja ocjenjivanje, kušanje, kvalifikaciju i cijene proizvoda. Govori i o komunikaciji, mostovima, rijekama i putovima. Stil mu je jednostavan i piše dnevnik koji nema književnih nakana. Poznavao je francuski i latinski te drevne rimske putove i ostale onodobne starine (Levental 1989: 174-175).

RICHARD POCKOCKE, A Description of the East and some other Countries. Vol. I-II. London 1745 (W. Bowyer, London 1745.)

1745.

Richard Pockocke je bio engleski svećenik te generalni vikar u Lismoreu. Godine 1745. putovao je na jugoistok kroz Mađarsku, Hrvatsku, Štajersku, Korušku, Goričku i Kranjsku te Istru. S obzirom na zanimanje, ne zadržava se samo na argumentiranju diplomatskih i političkih prilika, država i granica, niti na suvremenom životu naroda s kojima dolazi u doticaj, već su mu u prvom planu bile kultura, starine, umjetnost i povijest. ${ }^{6}$ (Levental 1989 : 207-209).

http://www.kartografija.hr/old_hkd/kartzadra/Katalog/Coronelli.htm (23.10.2013.).

U svojim opisima i bilješkama često citira antičke pisce. 
VITALIANO DONATI, LIONARDO SESLER, Della storia naturale marina dell'Adriatico' (Francesco Storti, Venecija 1750.)

1750.

Vitaliano Donati bio je liječnik, arheolog i botaničar. Napisao je zajedno s venecijanskim liječnikom i botaničarom Leonardom Seslerom knjigu o morskoj flori i fauni na Jadranu. U nekoliko navrata spominje Rovinj. Detaljno opisuje i crta biljni i životinjski svijet koji je promatrao i proučio kod Rovinja i Vrsara (Donati - Sesler 1750: LIV). Proučavao je mramore i fosile.

U XVIII. su stoljeću mnogi stručnjaci dolazili u Istru i Dalmaciju pogledati, istražiti i raspravljati o okamenjenim ljudskim kostima na hridima, otocima i drugdje. U Istri, Morlakiji, Dalmaciji i Albaniji su hridi, otoci i morsko dno formirani od jedne jedine stijene neprozirnog mramora, zrnatog sastava, skoro iste tvrdoće, bjelkaste boje; to je onaj isti mramor koji se u "Italiji" (da noi) poznaje kao "Marmo di Rovigno", a u prošlosti se nazivao "Traguriense" (Donati - Sesler 1750: VIII).

ROBERT ADAM - CHARLES LOUIS CLERISSEAU, Ruins of the Palace of the Emperor Diocletian at Spalatro in Dalmatia. By R. Adam FRS, FSA, Architect to the King and to the Queen. (Robert Adam, London 1764.)

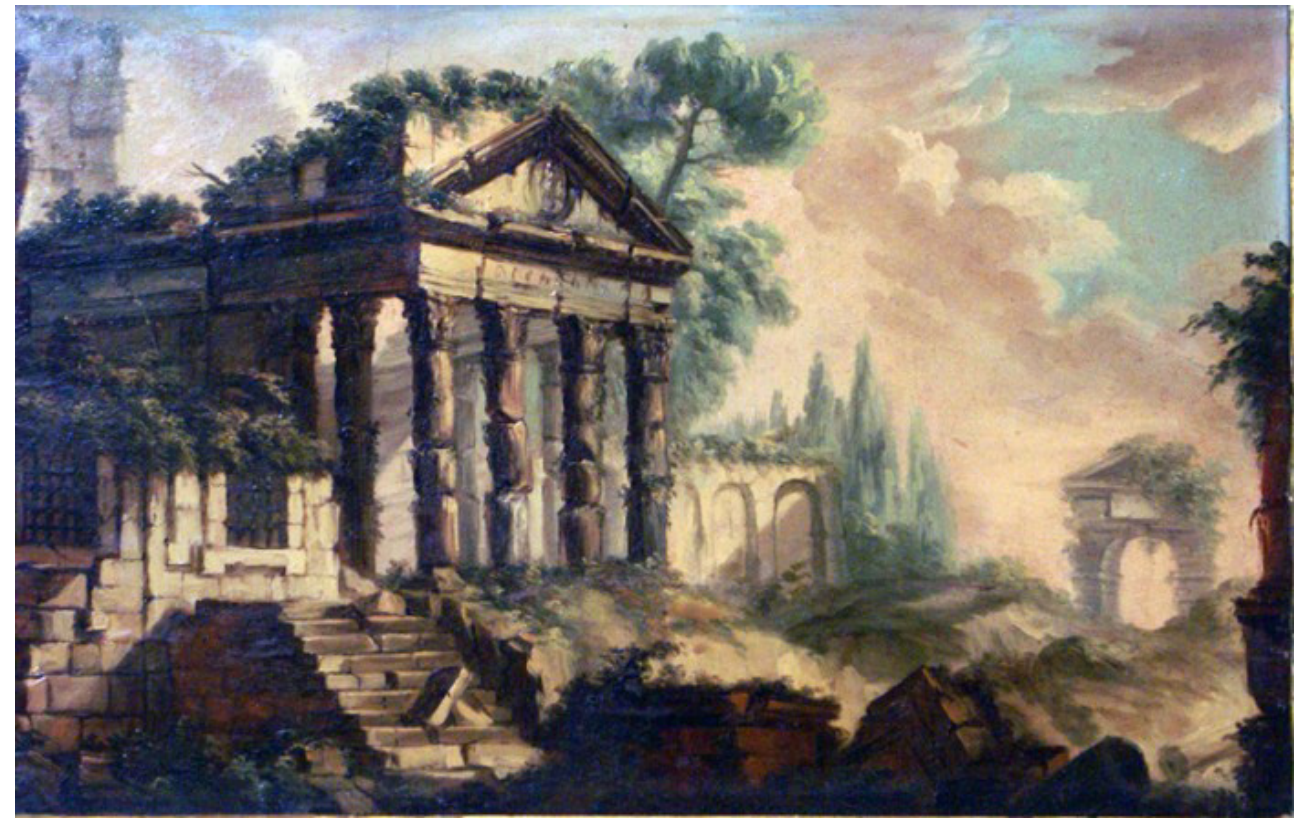

Sl. 4: Charles Louis Clerisseau, slika Augustova hrama u Puli

http://www.galleriatanca.it/charles-louis-clerisseau-scuola-di-coppia-di-peaseggi-con-rovine/sonydsc-7/ (23.10.2013.)

Knjiga je na internetskim stranicama u digitaliziranom obliku:

http://books.google.hr/books?id=aiSGg2lvhMkC\&pg=PP1\&lpg=PP1\&dq=vitaliano+donati+della+storia+natura le+marina+dell\%27adriatico\&source=bl\&ots=EzMYCmsiq1\&sig=8iFqJn4cWybedJpdOhoxAyuOQyo\&hl=hr\&ei=YmxTsi5Hc3t-ga1sLn9AQ\&sa=X\&oi=book_result\&ct=result\&resnum=3\&ved=0CC0Q6AEwAg\# $\mathrm{v}=$ onepage $\& \mathrm{q}=$ rovigno\&f=false $(23.10 .2013$.). 
1757.

Robert Adam, član Kraljevskog društva i član Društva starina, dvorski arhitekt, mnogo je vremena boravio u Italiji, a tri je godine studirao graditeljstvo u Rimu. Opisi, mjere, općenito djela antičkih autora poput Plinija i Vitruvija te dobro sačuvani rimski spomenici, ponukali su ga da ode do Splita i pogleda Dioklecijanovu palaču. Tvrdio je da su starine za arhitekta ono što je za umjetnika priroda (Levental 189: 210). Svojim djelom htio je zadovoljiti vlastiti interes, ali i potaknuti zanimanja javnosti za starine (Krmpotić 1997: 65-66). U društvu francuskog umjetnika Charlesa Louisa Clerisseaua otplovio je iz Venecije u Split. Nismo sigurni je li se zaustavio u Istri, poglavito Puli, uobičajenoj etapi na ruti iz Venecije u Dalmaciju.

Mletački namjesnici zazirali su od putnika putopisaca i njihovih tekstova, misleći da se među njima krije špijunska mreža (Zlodi 2007: 188). Često se strance ispitivalo, a neugodnosti su doživjeli i Adam i Clerisseau koji su na nekoliko dana morali zaustaviti započeti posao (Krmpotić 1997: 66).

ALBERTO FORTIS, Viaggio in Dalmazia dell'abate Alberto Fortis (Alvise Milocco, Venecija 1774.)

1765.-1791.

Alberto Fortis rodio se u Padovi 9. studenog 1741. Otac mu je bio plemić, a majka očeva druga žena. Zaredio se i postao opat. ${ }^{8}$ lako nije uspio postati profesor na sveučilištu, volio je prirodoslovne znanosti i od djetinjstva je bio okružen sveučilišnim profesorima.

Prvi je put posjetio Istru 1765. godine, kada dolazi do Pule i Valture. Posjećuje brojna mjesta pod mletačkom vlašću na kvarnerskoj obali, sve do ušća rijeke Raše. Istra se našla i u djelima Fortisovog drugog prijatelja, Johna Symondsa.

Stopama sugrađanina Vitaliana Donatija i na tragu saznanja da u Dalmaciji ima okamenjenih kostiju kopnenih životinja i ljudi, krenuli su Fortis i njegovi mecene (gosp. Symonds i prof. Cirilli) na kvarnerske Apsirtide. Na povratku su pristali kraj Novigrada, kako bi razgledali znamenitu špilju Mramornicu kod Brtonigle ("la celebre foiba di Verteneglio").

Naslov izvornika u kojem daje opis Dalmacije glasi "Viaggio in Dalmazia dell'abate Alberto Fortis", a tiskan je u Veneciji 1774. Fortis se ponajprije bavio etnologijom.

JOSEPH VON SEENUS, Beschreibung einer Reise nach Istrien und Dalmatien (J. C. Monath und J. F. Kussler, Nürnberg 1805.)

1768.

Osamnaesto je stoljeće razdoblje u kojemu u austrijskim znanstvenim krugovima vlada priličan interes za raslinje i botaniku pa se pojavljuju i tekstovi putopisnog karaktera. Veliko zanimanje za Alpe natjeralo je von Seenusa da napusti planinski lanac koji danas dijeli Italiju, Austriju i Švicarsku i poželi istražiti sasvim drugo podneblje.

U djelu "Beschreibung einer Reise nach Istrien und Dalmatien" izvješćuje o manirama starosjedilaca koje je susretao.

BALTHASAR HACQUET (1735-1815), Oslikavanje iopisivanje jugozapadnih i istočnih Wenda, Ilira i Slavena, njihove zemljopisne rasprostranjenosti od Jadranskog pa sve do Crnog mora, njihova života i običaja, zanata i obrta, religije, itd., a po povratku s desetogodišnjeg proputovanja i četrdesetogodišnjeg boravka u tim krajevima (Etnografski muzej Split, Split 2008.)

Velika je vjerojatnost, po Muljačiću, da Fortis nije nikada ni postao opat ni svećenik, već je imao samo tri niža sveta reda koja su mu dopuštala da nosi svećeničku odjeću, no nije smio dijeliti sakramente (Muljačić 1996.). 


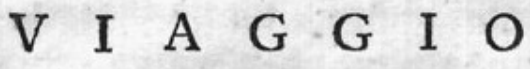

I $\mathrm{N}$

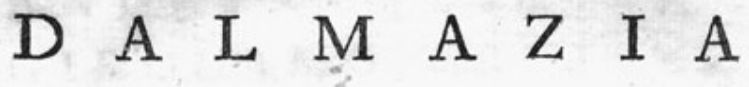 \\ D E L L'}

ABATE ALBERTO FORTIS.

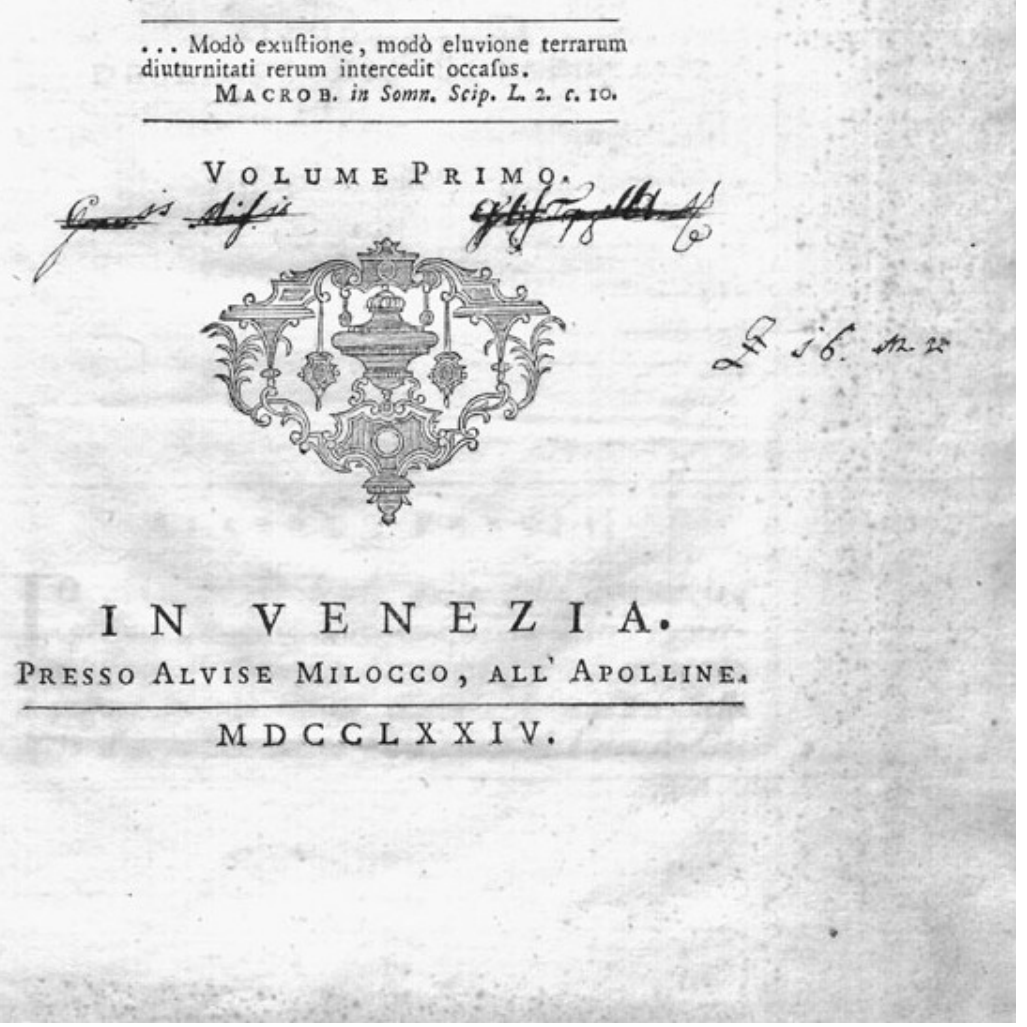

SI. 5: Naslovnica Fortisove knjige "Viaggio in Dalmazia"

http://www.library.yale.edu/slavic/croatia/history/ (23.10.2013.)

1774.

Oi Sarajevo seto sini neveselo

Jelimiteje Kuga pomorisa

Alimityi Turesin porobio.

- Oj, ti Sarajevo, zašto li si tako tužno, je li te je kuga raselila opustošila, ili su te Turci porobili? (Hacquet 2008: 85). 
Balthasar Hacquet (na nekim bakrorezima i Belsazar) bio je neumorni putnik koji je, kao što vidimo u naslovu njegove knjige, četrdeset godina boravio u našim krajevima. ${ }^{9}$ Tko je, dakle, pozvaniji od njega za opisivanje slavenskih naroda iz zapadnoeuropske perspektive i stajališta? No, nije sve u tome. Putnik nam je ostavio "oporuku" koja sadrži najiscrpnije etnološko djelo o Slavenima, njihovim običajima, obrtima, zanimanjima, strukturi društva i tijela, folkloru, odjeći, hrani. Ipak, sve njegove izjave i tvrdnje treba uzeti s oprezom. Ima puno improvizacija i neistina, kao i površnih tvrdnji. Izgleda da je Hacquet poznavao hrvatski jezik (Pederin 1991, 37-38).

$\mathrm{U}$ djelu "Abbildung und Beschreibung der südwest- und östlichen Wenden, Illyren und Slaven" pregledao je "oslikavanje i opisivanje jugozapadnih i istočnih Wenda, Ilira i Slavena, njihove zemljopisne rasprostranjenosti od Jadranskog pa sve do Crnog mora, njihova života i običaja, zanata i obrta, religije, itd., a po povratku s desetogodišnjeg proputovanja i četrdesetogodišnjeg boravka u tim krajevima". Hacquet je na Balkanu u širem smislu boravio četrdesetak godina te je po povratku u domovinu napisao iznimno djelo.

JOHN SYMONDS, On the effect of water in the agriculture of Italy" $u$ "Annals of Agriculture, and other useful arts. Collected and published by Arthur Young, Esq. F. R. S. VOL. I. London: Printed by H. Goldney, No. 15, Paternoster-Row; and fold by all the Booksellers in London and Westminster. M. DCC LXXXIV (Arthur Young, London 1784.)

1784.-1786.; 1790.-1791.

Fortis Johna Symondsa naziva "Cavaliere". On je istaknuti britanski učenjak s kojim je talijanski "opat” došao u vezu 1769. godine (Muljačić 1996: 22). Pravnik po struci, započinje karijeru profesora moderne povijesti i objavljuje svoje bilješke o suvremenoj talijanskoj poljoprivredi. Njegovo je pero pronašlo prostor u knjizi agronoma Arthura Younga. U "Annals of Agriculture, and other useful arts. Collected and published by Arthur Young, Esq. F. R. S. VOL. I. London: Printed by H. Goldney, No. 15, Paternoster-Row; and fold by all the Booksellers in London and Westminster. M. DCC LXXXIV" Symonds piše članak "On the effect of water in the agriculture of Italy". Na 430. stranici piše da treba spomenuti onih nekoliko mjesta u Italiji koja se bore s problemom nedostatka vode. U tim rečenicama svoje mjesto nalaze istarska naselja.

THOMAS WATKINS, Travels through Switzerland, Italy, Sicily, the Greek Islands to Constantinople, through part of Greece, Ragusa, and the Dalmatian Isles; In a Series of Letters to Pennyre Watkins, Esq. from Thomas Watkins, Am. F. R. S. in the Years 1787, 1788, 1789. Vol. I-II (J. Owen, London 1794.)

\section{7.-1789.}

Thomas Watkins osam je mjeseci putovao Istokom i nije mogao sakriti radost kad je na povratku ugledao venecijanske otoke (Levental 1989: 233). Njegov je stil istovremeno misteriozan, jasan, živahan, vrlo zanimljiv i slikovit. Shvaća da putovati može biti jako opasno i kobno. Jasno je po njegovom pisanju da otkada je 19. srpnja odjedrio iz Venecije i odmaknuo se od kopna, nije više imao nikakav utjecaj na svoj vlastiti put. Bio je prepušten milosti i nemilosti vjetra i mora koji su ga odveli do obale Istre, jako blizu Puli, nakon čega se smjer vjetra okrenuo udaljivši ga od obale i vrativši ga na pučinu. Watkins citira Plinija Starijeg, Kolhiđane i rimski naziv Pule, Iulia Pietas. Otvoreno izražava nezadovoljstvo što nije uspio pogledati takozvani najljepši amfiteatar na svijetu (Levental 1989: 229-233).

Podatak se ponavlja na početku uvoda: Isto, str. 10. 
ANONIMNI AUTOR, Kurzgefasste geographisch-statistische Beschreibung des $k . \quad k$. Herzogthums Venedig und des damit verbunden Dalmatien und Albanien (Pederin 1991: 53-54).

1798.

Nakon austrijskog zauzimanja Istre i Dalmacije, u Beč su počele stizati informacije o tim južnim zemljama i njihovom pučanstvu. Bezimeni je autor 1798. izdao djelo "Kurzgefasste geographisch-statistische Beschreibung des k. k. Herzogthums Venedig und des damit verbunden Dalmatien und Albanien" (Pederin 1991: 53-54). U tekstu se dotaknuo Istre i njezina uljarstva, pčelarstva i vinogradarstva.

\section{Putnici putopisci u Istri u XIX. stoljeću}

ERNST FRIEDRICH GERMAR, Reise nach Dalmatien und in das Gebiet von Ragusa (F. A. Brockhau, Leipzig i Altenburg 1817.)

1817.

Germar je bio prirodoslovac (1786.-1853.) i ravnatelj Mineraloškog muzeja u Halleu (Njemačka), koji je u Dalmaciju otputovao zaintrigiran ranijim opisima von Seenusa i Hacqueta. Putopis je naslovio "Reise nach Dalmatien und in das Gebiet von Ragusa” (Leipzig und Altenberg, 1817. $)^{10}$ Napisao je da stanovništvo Istre svoj jezik naziva hrvatskim, na sjeveru i slovenskim (crainisch). Prema tim zapisima, zaključujemo da su hrvatska i slovenska svijest u Istri već bile razvijene kod njezina pučanstva ${ }^{11}$.

JOSEPH MARX FREIHERR VON LIECHTENSTERN, Reisen durch das österreichische Illyrien, Dalmatien und Albanien im Jahre 1818 (F. W. Goedschke, Meissen 1822.) 1818.

Propašću Napoleonovog carstva, Austrija je ponovno zavladala Istrom i Dalmacijom i probudila zanimanje za te zemlje. Feldmaršal-lajtnant von Liechtenstern je 1818. proputovao po austrijskom jugu i zapisao impresije u djelu tiskanom 1822. u Meissenu. Djelo je u dva sveska tiskao izdavač F. W. Geodschka s naslovom: "Reisen durch das österreichische Illyrien, Dalmatien und Albanien im Jahre 1818". Istru spominje kada zapisuje pustolovnu zgodu o napadu hajduka, kojem se uspio oduprijeti (Pederin 1991: 62-63).

THOMAS ALLASON, Picturesque Views Of The Antiquities Of Pola (John Murray, London 1819.)

1819.

Allason je bio engleski arhitekt, zemljomjernik i umjetnik (1790.-1852.), koji je na putu za Grčku prošao Pulom. Usredotočen na povijesni razvoj krajeva kroz koje je putovao, Allason je koristio publikacije i istraživanja, prije svega one Alberta Fortisa. Objavio je knjigu pod naslovom "Picturesque Views Of The Antiquities Of Pola". Zanimali su ga narodi i etničke skupine prema kojima je bio dobronamjeran i lišen svih predrasuda. Za Istru i Dalmaciju kaže da zaslužuju pažnju ljubitelja starina i znanosti. Allason smatra da bi svaki putnik trebao biti osjećajan te nimalo ravnodušan prema onome što obilazi i posjećuje. Svaku korisnu knjigu mora pokrenuti srce, svako saznanje koje teži trajnosti mora biti zasnovano na osjećajima.

$10 \quad$ Njegov put je opisao R. Maixner, Le voyage aventureux d’Ernst Friedrich Germar dans les provinces illyriennes (1811), Annales de l'Institut Francais de Zagreb, 5 (1941.), 18-19, 210-216 (Pederin 1991: 60.).

11 E. F. Germar, op. cit., str. 62., 89., 96., u: Pederin 1991: 61. 
Stoga je većina knjiga osuđena na smrt u prašini. Manje bi se izbjegavalo učenje kada bi pisanje bilo usmjereno k srcu umjesto k umu. Zadaća genija je otkriti poveznicu između srca i nauke (Levental 1989: 252-253).

Sir HUMPHRY DAVY, Pola or Time u Consolations in travel; or the last days of a philosopher. London MDCCCXXXI. (Cassell \& Company, London 1889.)

$<1831$.

Vrlo su zanimljiva razmatranja naturalista Sira Humphryja Davyja pod naslovom "Pola or Time" u knjizi "Consolations in travel; or the last days of a philosopher. London MDCCCXXXI."

Sir Humprhy Davy, britanski naturalist koji je bio jako cijenjen zbog pojedinih otkrića, piše da je bio smješten u Iliriji i da je jednog dana odlučio posjetiti Pulu. Plovio je u "felluchi" i opisuje ulaz u pulsku luku u suton, kako ga je on doživio, najljepšim na svijetu. Fascinirao ga je pogled na drevni amfiteatar.

Opisuje Pulu koristeći oblik razgovora troje likova. Oni raspravljaju o prirodnim, znanstvenim i svakojakim pojedinostima naše zemlje koju uspoređuju sa svima koje su dotad već posjetili ili su o njima čitali i učili. Rasprava tako dobiva vjerodostojnu dimenziju te se daje naslutiti da je riječ o pravom znanstveniku, a ne više o prolaznom putniku u potrazi za pustolovinom. ${ }^{12}$

ANTON JOHANN GROSS-HOFFINGER, Handbuch für Reisende durch die österreichische Monarchie, mit besonderer Rücksicht auf die südlichen und Gebirgsländer, naämlich: Oesterreich, Salzburg, Steiermark, Illirien, Tyrol, das lombardisch-venetianische Königreich und Dalmatien, nebst Meilenzeiger und alphabetischem Ortsregiste (Joseph Lindauer'sche Buchhandlung, München 1834.)

1831.

Austrijski književnik (1808.-1873.), objavio je 1831. putnički priručnik “Handbuch für Reisende durch das Erz-Herzogthum Österreich, Steiermark, Salzburg, Krain, Kärnten, Tyrol, Illyrien Dalmatien und das lombardisch-venetianische Königreich", koji, između ostalog, obuhvaća i opise Istre.

EDMUND SPENCER, Sketches of Germany and the Germans, with a Glance at Poland, Hungary, \& Switzerland, in 1834, 1835, and 1836. By an Englishman Resident in Germany. In two Volumes (Whittaker \& co., London 1836.)

1834.-1836.

Edmund Spencer je 1836. u Londonu objelodanio razmatranja i zapažanja svojega putovanja pod naslovom "Sketches of Germany and the Germans, with a Glance at Poland, Hungary, \& Switzerland, in 1834, 1835, and 1836. By an Englishman Resident in Germany. In two Volumes".

I Edmund Spencer je još prije polaska od nekog čuo da je upravo pulski amfiteatar najbolje očuvan na svijetu. Promatrajući ga, otvoreno mašta o tome kako je Arena sagrađena s ciljem da carevi i narodi okupljeni uživaju u tuđoj patnji i smrti nedužnih životinja i ljudi. U svom tekstu naglašava da se radilo o civiliziranim i akulturiranim ljudima i retorički se pita koliko onda trebamo zahvaliti kršćanstvu što je okrutnost pretvorilo u nešto zaista pohvalno i očovječilo narode, misli i njihove osjećaje (Levental 1989: 285-286).

Nakon što se njegov brod otisnuo iz pulskog zaljeva, zaobišli su rt Kamenjak i zastali na Cresu.

12 http://www.gutenberg.org/files/17882/17882-h/17882-h.htm (23.10.2013.). 
ADALBERT VON LADENBERG, Reise durch Oesterreich nach Konstantinopel und Triest, Hamburg, 1839 (Hoffmann \& Campe, Hamburg 1839.)

1836.

Bio je pruski političar (1798.-1855.) koji je 1836. putovao kopnom u Konstantinopol, a odande se vraćao brodom jedreći uz hrvatsku obalu. Spominje samo Dubrovnik te strateško važne Vis, Hvar i Pulu (Pederin 1991: 114). Kod njega prevladavaju loši dojmovi s broda i putovanja, više nego pojedinosti o krajevima kroz koje je putovao. Kaže da je kapetan bio neobrazovan i da je govorio samo hrvatski i ponešto talijanski. Požalio se da je u kabini bilo štakora.

BARTOLOMEO BIASOLETTO / FRIEDRICH AUGUST, Relazione del viaggio fatto nella primavera del 1838 dalla Maestà del Re Federico Augusto di Sassonia nell'Istria, Dalmazia e Monte Negro (Favarger, Trieste 1841.)

1838.

Friedrich August II. bio je saski kralj (1797.-1854.), koji je na prijestolje sjeo 1837. Iste je godine otvorena brodska linija Trst-Carigrad, a među prvima koji su je iskoristili bio je i on, veliki ljubitelj prirodoslovlja i prirode, posebice botanike. Želio je ostati nepoznat pa je putovao pod imenom grofa Hochensteina, a 1838. godine posjetio je Klek, Velebit, Biokovo, Učku i Zmijsko brdo na Pelješcu. Na Učki mu je pratitelj bio Bartolomeo Biasoletto, rodom iz Vodnjana, koji je 1841. objavio knjigu "Relazione del viaggio fatto nella primavera del 1838 dalla Maestà del Re Federico Augusto di Sassonia nell'Istria, Dalmazia e Monte Negro", tiskanu u Trstu.

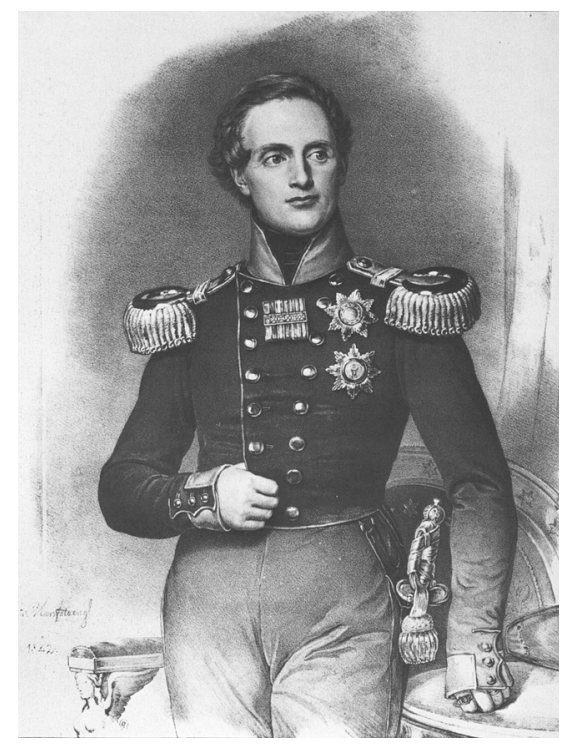

SI. 6: Friedrich August II., Saski kralj, portret

http://upload.wikimedia.org/wikipedia/commons/a/a9/Friedrich_August\%2C_König_von_Sachsen. jpg (23.10.2013.). 
AUGUST TISCHBEIN i AUGUST SELB, Memorie di un viaggio pittorico nel Litorale austriaco (Favarger, Trieste 1842.)

1842.

August Tischbein je bio njemački slikar (1805.-1867.), koji je dugo živio u Trstu, a August Selb njemački slikar i litograf (1812.-1859.). Oni su u Trstu počeli surađivati pa su krenuli sa slikarskom opremom kako bi oslikali vedute, krajolike i zadivljujuće panorame od Ogleja/ Akvileje (Aquileia) do Lošinja. Za objavu su priredili četrdesetak veduta gradova ili drugih važnih predjela, koje je Kandler popratio tekstom (Tischbein, Selb 1997: 12). Knjigu su naslovili "Memorie di un viaggio pittorico nel Litorale austriaco".

HEINRICH STIEGLITZ, Istrien und Dalmatien, Briefe und Erinnerungen (J. G. Cotta'schen Buchhandlung, Stuttgart i Tübingen 1845.)

1843.

Stieglitz je bio njemački pjesnik (1801.-1849.), koji je putovao po Europi i Istoku, pa je tako objavio knjigu "Istrien und Dalmatien, Briefe und Erinnerungen" (Stuttgart und Tübingen, 1845.), koju je posvetio virtemberškom ministru Karlu Augustu von Wangenheimu (Pederin 1991: 116-117). U Trst je stigao 1843. te je odatle proputovao Istrom i Kvarnerom. Oslonio se na istarsku srednjovjekovnu povijest pa je u Pazinu, gdje je nekada na vlasti bio njemački feudalizam, vidio prijestolnicu Istre. Tako i u Puli opisuje habsburškog orla i povezuje ga s rimskim. Svjetski se duh razvijao pod Mlečanima, potom Francuzima i tek se istinski trijumfalno ostvaruje u austrijskoj vlasti. O Areni je napisao pomalo nacionalističku pjesmu. Okolnosti da u Istri i Dalmaciji brojčano prevladavaju Hrvati njega ne zanimaju previše. Više ga smetaju Talijani, a to zato jer su, za razliku od potonjih, politički organiziraniji i moćniji. Bili su i dosta brojni. Stoga poziva svoje sunarodnjake da se posvete osamostaljivanju Istre i Dalmacije, umjesto da naseljavaju Ameriku (Pederin 1991: 118-119). U duhu romantičarskog stila, ploveći Kvarnerom pod zvijezdama, zamišlja kako se u jednoj takvoj noći Vergilijev Palinur utopio, a u Osoru prepoznaje otok gdje je Medeja nagovorila Jazona da ubije brata i šurjaka (Pederin 1991: 119-121).

BERNARD FIEDLER, Die Arena in Pola (1853.) (Pederin 1991: 129) 1840.

Bernard Fiedler bio je slikar koji se rodio i školovao u Berlinu (1816.-1904.). Veći dio života proveo je na putovanjima, a najviše se zadržavao na talijanskom i austrijskom području. Austrijski Lloyd, tvrtka za prijevoz pošte s glavnom lukom u Trstu, četrdesetih godina XIX. stoljeća proširuje usluge i na prijevoz putnika. K tome se 1857 . otvara i Južna željeznica (Südbahn) koja je tršćansku pomorsku luku povezala s glavnim gradom carstva (Pederin 1991: 179). Do povećanja gostiju dolazilo se reklamom, pa je Lloyd počeo o svom trošku pozivati slikare i pisce, a inaugurira također odjel za publikaciju, koji putem zabavnih članaka želi privući goste na jadransko putovanje (Pederin 1991: 129). Fiedler je također i putovao od Venecije, preko Dalmacije do Levanta.

JOHN GARDNER WILKINSON, Dalmatia and Montenegro with a Journey to Mostar in Herzegovina and Remarks on the Slavonic Nations, the History of Dalmatia and Ragusa, the Uskoks... (J. Murray, London 1848.) 
1848.

Ugledni egiptolog i potpredsjednik British Archaeological Associationa (1797.-1875.) napisao je knjigu "Dalmatia and Montenegro with a Journey to Mostar in Herzegovina and Remarks on the Slavonic Nations, the History of Dalmatia and Ragusa, the Uskoks..." koja je tiskana u Londonu 1848. (Pederin 1991: 135). Nekoliko godina prije proputovao je Istru i Dalmaciju, a u tekstu je spomenuo Pulu, Rovinj i Poreč, kao i druge istarske gradove. Istarski prostor bio je poprište razmirica i malih ratova između uskoka, skupina Albanaca, Turaka, Mlečana i dr.

JOHANN GEORG KOHL, Reise nach Istrien, Dalmatien und Montenegro (Arnold, Dresden 1851.)

1850.

Njemački zemljopisac, putnik i pisac (1808.-1878), studirao je u Heidelbergu, Göttingenu i Münchenu te bio veliki putnik koji je prošao cijelu Europu i Ameriku, a 1850. posjetio je Istru i Dalmaciju. Na povratku je napisao knjigu "Reise nach Istrien, Dalmatien und Montenegro", Dresden 1851.

Autor opaža da istarski ćići govore rumunjski (Pederin 1991: 146). Začudilo ga je kako se samo ovdje u cijelom katoličkom svijetu, uz papino dopuštenje, misa čita na materinskom jeziku. I misali su pisani nekim pismom koje nije ni ćirilica ni latinica (očito se radi o glagoljici). U slavenskoj Istri njemački ima dakako manje ugleda od talijanskog. Njemački nitko ne uči, a Stieglitzova feudalna Njemačka se sačuvala samo u arhivskim vrelima, od kojih Kohl prenosi jedno pismo na njemačkom. ${ }^{13}$

Kohl je ljubitelj starina i kulture općenito, tako da je opisao svaku važniju crkvu u Istri i Dalmaciji i posebno se zadržao na opisu Eufrazijeve bazilike u Poreču (Pederin 1991: 148).

AUGUSTIN TROGHER, Briefe während einer Reise durch Istrien, Dalmatien, Albanien, SüdItalien, Spanien, Portugal, Madeira und einem Teile der Westküste Afrika's (Schimpff's Buchhandlung, Trst 1855.)

1855.

Austrijski liječnik Augustin Josef Leopold Trogher (1810.-1858.) pratio je nadvojvodu Ferdinanda Maksa na njegovom velikom putu na regati "Novara", nakon čega izdaje putopis pod naslovom "Briefe während einer Reise durch Istrien, Dalmatien, Albanien, Süd-Italien, Spanien, Portugal, Madeira und einem Teile der Westküste Afrika's" (Triest, F: H: Schimpff's Buchhandlung, 1855.). Trogher opaža i uspoređuje kako najprije učimo strane jezike, a tek poslije materinski. Isto se tako u njegovo doba prije putovalo u Afriku i Ameriku, a Dalmacija i Istra ostale su izvan putničkih uobičajenih ruta. Ovo pokazuje da se naše priobalje smatra austrijskim državnim ozemljem, što se uklapa u apsolutističku ideju stvaranja austrijske nacije (Pederin 1991: 173). Sada se u ovom podneblju nalaze ljekovita svojstva i uzdižu njezine ljepote u svrhu turizma.

ALEXANDER RITTER VON GORACUCHI, Die Adria und ihre Küsten mit Betrachtungen über Triest als Badeort nebst einer Erörterung ber das Seewasser und dessen heilbringende Wirkung von J. Alexander Ritter v. Goracuchi, Doctor der Medizin (Buchdruckerei des Oesterreichischen Lloyd, Trst 1863.)

13 J. G. Kohl, op. cit., 1., str. 455.-456., u: I. Pederin, Jadranska Hrvatska u austrijskim i njemačkim putopisima, 148. 
1863.

I Alexander von Goracuchi bio je liječnik koji je putovao Jadranom i potom objavio knjigu o Jadranskom moru i njegovim obalama, ali s dva dodatka: o Trstu kao kupališnom mjestu i o ljekovitom učinku morske vode: "Die Adria und ihre Küsten mit Betrachtungen über Triest als Badeort nebst einer Erörterung ber das Seewasser und dessen heilbringende Wirkung von J. Alexander Ritter v. Goracuchi, Doctor der Medizin" (Triest, Buchdruckerei des Oesterreichischen Lloyd, 1863.). Kao pravi znanstvenik, on mjeri temperaturu mora, obrazlaže ljekovita svojstva morske soli i vode, uspoređuje razna europska i svjetska mora, mjeri dubinu i mnoge druge karakteristike Jadrana, piše o ljetovalištima, morskim bolestima, idealnim uvjetima za kupanje, trajanju kupanja i drugim povoljnim čimbenicima; spominje idealnu hranu i piće za kupače; istražuje dno i alge, morsku i kopnenu floru i faunu, koralje i školjke, delfine i danas vrlo rijetku sredozemnu medvjedicu, itd. (Von Goracuchi 1863: 97).

\section{ALEXANDER VON WARSBERG, Odyseische Landschaften (C. Gerold, Beč 1879.)} 1871.

Njemački putnik i pisac (1836.-1889.), putuje Jadranom i idealizira ga. Njegovi spisi, prožeti maštovitim slikama, donose i podatke o Poreču i Puli u rimsko doba. Zamišlja kako su izgledali ljetnikovci na istarskoj obali prije dvije tisuće godina. Po njemu, Sava je zacijelo Ister, koji spominje Apolonije Rođanin. Von Warsbergova knjiga je štampana 1871. pod naslovom "Odyseische Landschaften".

\section{CHARLES YRIARTE, Istria y Dalmatia (Montaner y Simon Editores, Barcelona 1878.)}

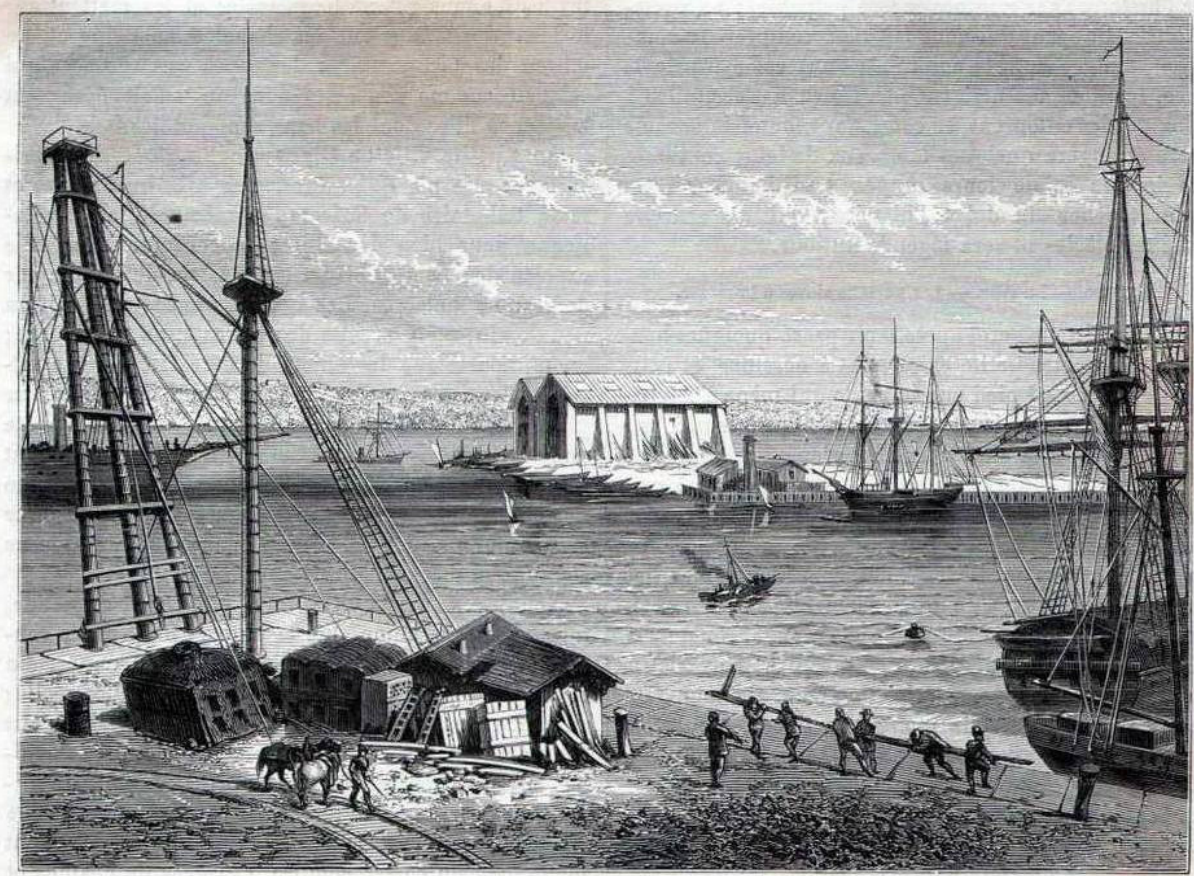

Vue intérieure de l'arsenal de Pola : Les cales de radoub et l'écueil des Oliviers. - Dessin de J. Moynet, d'après un croquas de M. Ch. Yriarte.

SI. 7: Pogled na pulski arsenal; Moynetov crtež nastao na temelju Yriarteove skice 
1874.

Charles Yriarte je bio podrijetlom iz Baskije, iako je živio u Parizu, gdje se i obrazovao. Opisao je narode, ljude i njihove običaje od Venecije do Crne Gore. Intelektualni krugovi Pariza i Europe u njegovo su doba inzistirali na romantičarskim opisima života i naroda. Taj je duh djelovao i na Yriartea, koji je na putovanjima otkrivao seosku arkadiju gdje su ljudi nekorumpirani, snažni i zdravi. Njegovi su opisi, napose onaj pazinske jame i kaštela, inspirirali Julesa Vernea, koji nikada nije bio u Istri, te ga potaknuli da roman "Mathias Sandorf" smjesti upravo u Istru (Yriarte 1878).

Istru opisuje od 633. do 678. stranice, a u tekstu daje opširne opise gradova i preciznu etnološku sliku posjećenih krajeva. Pored poznatih dijelova Istre, posebice ga zanimaju sela i manje poznata mjesta. Putopis je naslovljen "Istria y Dalmatia".

RICHARD FRANCIS BURTON, Note sopra i castellieri o rovine preistoriche della penisola istriana del capitano R. F. Burton (B. Appolonio, Trst 1877.)

1874.

Richard Francis Burton vjerojatno je jedna od najuglednijih europskih povijesnih ličnosti koja je posjetila naš kraj te se njime bavila i o njemu pisala. Burton je plijenio pozornost za života, a njegova smrt i pokop bili su prvorazredni društveni događaj (Valentini 1998: 14). Burton je bio svestran čovjek, poznavao je tridesetak jezika, ne računajući brojne dijalekte (Lowell 1999: XVII).

Talijanska verzija dijela njegovih tekstova prevedena je i tiskana u Kopru 1877. godine. Knjiga obuhvaća Burtonova razmatranja i istraživanja istarskih gradina, odnosno ostataka prapovijesnih naselja. Autor je u to doba bio engleski konzul u Trstu i član antropološkog društva u Londonu. Iscrpnu je građu o Istri Burton skupio u djelu "Note sopra i castellieri o rovine preistoriche della penisola istriana del capitano R. F. Burton".

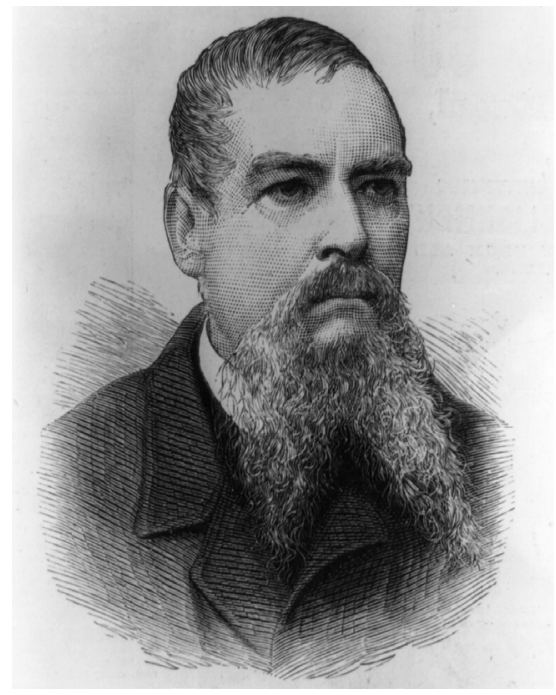

SI. 8: Sir Francis Richard Burton, portret

http://en.wikipedia.org/wiki/File:ST-Burton.jpg (23.10.2013.) 
CARL/KARL DU PREL, Unter Tannen und Pinien, Wanderungen in den Alpen, Italien, Dalmatien und Montenegro (Denicke, Berlin 1875.)

1879.

Njemački (bavarski) filozof, učenik Arthura Schopenhauera (1839.-1899). Knjiga mu je tiskana u Berlinu 1879. U svom djelu spominje Pulu.

HEINRICH NOÉ, Wanderungen in und aus dem österreichischen Küstenlande, Krain, Istrien und den benachbarten Alpengebieten (C. Flemming, Glogau 1888.)

1880.>

Južnotirolski (austrijski) pisac putopisa i romana (1835.-1896), napisao je djela "Tagebuch aus Abbazia" (Teschen, 1884.), "Geleitbuch nach Süden, auf den Karst, nach Abbazia und auf die Adria. Ansichten von Wald, Lorbeerstrand und Meer" (Neue Ausgabe, München 1899.), te nama najvažniji "Wanderungen in und aus dem österreichischen Küstenlande, Krain, Istrien und den benachbarten Alpengebieten" (Glogau, 1888.).

ARMAND VON SCHWEIGER-LERCHENFELD, Die Adria, Land - und Seefahrten im Bereiche des Adriatischen Meeres (A. Hartleben, Beč 1883.)

1883.

Austrijski časnik, putnik i pisac (1846.-1910.) koji se 1866. borio protiv Prusa. Zaokupljen Jadranom, obilazi sve njegove obale, pa i talijanske, a zatim izdaje "Die Adria, Land - und Seefahrten im Bereiche des Adriatischen Meeres", Wien, 1883. Za Jadran kaže da je najljepši od svih europskih mora. Nastavlja da se nijedno drugo ne može s Jadranskim mjeriti, i dodaje, možda samo Egejsko more, ali i ono je manje koherentno od Jadrana (Pederin 1991: 2000).

\section{ZAKLUUČNA RAZMATRANJA}

Putopis nije jednostavan pojam. Ova riječ sažima vrlo kompleksne tekstove nastale kao rezultat promatranja neke pokrajine očima stranaca. Prikupili smo šezdeset putopisaca koji su proputovali našom pokrajinom i složili kratke opise njihovih djela - putopisa. Ni oni sami nisu bili svjesni koliko će njihove bilješke biti važne, koju će vrijednost one dobiti u budućnosti. Istražujući povijest, njihove smo zapise uzeli u ruke, prolistali opise naših gradova u nekim drugim epohama, pregledali slike važnih utvrda koje su danas zaboravljene, ali neke su i moćnije nego tada, podcrtali smo važnija zapažanja. Putopis je sam po sebi izvor jer ovjekovječuje trenutak povijesti u određenom mjestu, gradu, pokrajini, državi. Naravno da su neki od njih bili presudni u proučavanju određenih tema ili u stjecanju cjelovite slike jednog kraja u nekom trenutku.

Neki su putopisi pisani za razonodu, drugi iz vrlo praktičnih razloga, poput onih izvidničkih tekstova koje su uhode slale nalogodavcima. Bilo je i intelektualaca, znanstvenika koji su proučavali povijest kraja kroz koji su putovali. Bilo je ljubitelja starina, poput dr. Spona, koji je putovao sve do Grčke kako bi uživao u antičkim i helenističkim natpisima. Bilo je arhitekata, poput Serlija i Palladija, koji su u renesansnom duhu mjerili antičke spomenike kako bi kroz graditeljska ostvarenja oživjeli taj period u Italiji i Europi. Iz istih pobuda Pulu je posjetio i čuveni Michelangelo Buonarroti, najpoznatiji renesansni arhitekt i slikar kojemu je bio povjeren jedinstveni zadatak oslikavanja Sikstinske kapele u Vatikanu. Njegove skice pulskog Slavoluka čuvaju se u Lilleu. Istra je dala dobrodošlicu i prirodoslovcima.

Putopisi iz pera etnologa omogućuju usporedbu današnjih i ondašnjih običaja naroda koji žive na istom prostoru. U neku ruku otkrivaju promjene u razmišljanju, pokazuju neke detalje o nama samima koji bi inače bili zaboravljeni i izgubljeni. Balthasar Hacquet je vjerojatno najbolji 
putnik u povijesti putovanja Istrom. Ako ostavimo po strani njegova osobna stajališta, ostaje nam činjenica da je najpodrobnije obradio, opisao, oslikao istarsku hrvatsku kulturu i običaje onog vremena. Uživao je financijsku pomoć izravno iz Kuće Austrije te se mogao laskavo hvaliti prijateljstvom s carem Josipom II. Spoj ovih i nekih dubljih faktora dozvolio mu je dug boravak u našim krajevima, gdje je u dvadesetak godina odredio razliku između svih društvenih i etničkih skupina prisutnih na širem području Istre te ih podrobno opisao, zajedno s obredima, običajima, religijskim svetkovinama, tradicijskim tekovinama, itd.

U tekstovima ili na kartama putopisa neki su toponimi često pomiješani, izmijenjeni, pogrešno upisani ili se nalaze na krivom mjestu. Neki zalaze u Istru u potrazi za odgovorima ili kako bi usporedili pojedine karakteristike prirode s prethodnim saznanjima iz drugih mjesta. Pojedini su putopisci dolazili službeno, poput izdavača ili geografa, koji su trebali provjeriti zemljopisne mjere i udaljenosti. Istrom su putovali grofovi, knezovi, članovi Kraljevskog društva starina, liječnici, arheolozi, botaničari te mnogi drugi. Proučavali su morfologiju, fosile, posjećivali arheološke i povijesne lokalitete, zapisivali zanimljivosti. Robert Adam je objavio svoje djelo ne samo iz vlastitog zadovoljstva, već i da potakne i pobudi zanimanje javnosti za starine.

Ima i onih koji su se međusobno poznavali i družili pa su u visokim krugovima europske elite raspravljali o Istri. Od nekih saznajemo o nemaru ili brizi vlasti za ovaj kraj. Postoje oni koji se ljute, oni koji u nekim postupcima ili odnosima nalaze nepravdu. Većina njih, međutim, hvali amfiteatar u Puli kao najljepši na svijetu.

Alexander Ritter von Goracuchi jedan je od najzanimljivijih autora našeg popisa. Liječnik koji putuje brodom s kojeg mjeri temperaturu vode i bilježi botanička i slična zapažanja, navodi i neke pojedinosti koje mogu biti zaista nesvakidašnje.

Grijeh bi bio zaboraviti na Charlesa Yriartea, čiji su opisi Istre nadahnuli Julesa Vernea da upravo u Istru smjesti priču Mathiasa Sandorfa. Mathias je zatočen u pazinskom kaštelu zajedno s dvojicom prijatelja. Osuđeni su na smrt, ali Sandorf će uspjeti pobjeći...

Najistaknutija putopisna ličnost koja je ikada posjetila Istru, poslije Dantea, vjerojatno je Richard Burton, konzul, veleposlanik, jezikoslovac, dijalektolog, prevoditelj, povjesničar, arheolog te još mnogo toga. Nije mogao odoljeti šarmu istarskih kašteljera, koje je istraživao i o kojima je napisao čak dvije knjige.

U ovom smo radu nabrojali samo jedan dio "lutalica", manji dio istaknutijih ličnosti promatranog razdoblja, one koji su imali mogućnosti zapisivati svoje impresije te onu krajnju snagu i upornost da uspiju objelodaniti svoje zapise. Veći dio prolaznika, naime, mišljenje je o ovoj zemlji zadržao za sebe ili ga je zapisao pa, ne imajući načina da ga objavi, odnio sa sobom u grob. Samo su neki marginalci, poput Foxa (čije osobno ime ne znamo), koji je zapisao tekst putopisa za svoga gospodara Harryja Cavendisha. Imućan se Britanac nije potrudio ni pisati, već je i taj zadatak ostavio slugi, koji je o svemu već brinuo, od logistike do organizacije. Fox nam otkriva kako su jedne noći spavali u kokošinjcu, iduće na klupi, a tek su se nakon nekoliko noći smjestili na hrpu sijena, gdje su spavali kao "kraljevi".

Putnici zapažaju sve ono što je i danas tipično za Istru. Čude se kako se u Istri govore različiti dijalekti, od istrorumunjskog do istromletačkog, njemačkog i čakavskog. Zapažaju multikulturalnost, koja je i danas dio identiteta regije i koju ne znaju uvijek objasniti. Jasno im je da se nalaze u zemlji koja je razmeđa kultura, no nekad ih to zbunjuje. Uplovljavaju u relativno civilizirane gradove, pa se penju do najviših divljina Učke, zatim se preko Kvarnera udaljavaju prema zemlji uskoka ili prema otvorenom Jadranu, svom ukrašenom suhim, stjenovitim otocima.

Prešli smo kroz dugo razdoblje istarske povijesti i putovanja kroz poluotok. Svatko od autora je na sebi svojstven način vidio krajolike, vidike, slike trenutka koje je često stvarala 
mašta u suglasju s jedinstvenim prirodnim okruženjem. Svaki od njih vidio je, promišljao, zabilježio svoje osobne dojmove. Usporedbom dva putopisa iz istoga vremena nalazimo ponekad potpuno drukčije nazive i crteže. Razlog tome je loša informiranost, neznanje, lapidarnost u bilježenju činjenica. Mnogo onoga što su nekadašnji putnici Istrom zapisivali, opisivali, divili se ili prezirali, nažalost više nema, čime su njihova djela postala prava riznica informacija koje bi inače bile izgubljene. Njihov je rad "škrinja" uspomena, a uspomena nema bez pisanja, crtanja i proučavanja, jer ljudska memorija ne seže toliko daleko da bi se sjetila nečega što nije nikada mogla snimiti. Stoga postoje putopisci čije proučavanje treba smatrati legitimnim povijesnim izvorom, jer putopisi dopunjuju sliku prošlosti nekog kraja, njegovih ljudi i znamenitosti.

Putopisci su se s mora divili ranojutarnjem rumenilu hladnih zimskih jutra koje obgrljuje crkvu sv. Blaža u Vodnjanu, jednako su se divili kasnom ljetnom večernjem žutilu iza otoka Sv. Jurja kraj Vrsara ili blagoj svijetlo plavoj boji koja vijuga serpentinom niz obronke Lima. Ove su lutalice očaravali isti sutoni i ista svitanja koja mi danas gledamo. Sve su to komadići povijesti, a i mi smo dio nje...

\section{POPIS LITERATURE}

\section{ALIGHIERI 2010}

Dante Alighieri, La Divina Commedia, a cura di Anna Maria Chiavacci Leonardi, Mondadori, Milano 2010., Canto IX vv. 112-117.

\section{BERTOŠA 1995}

Miroslav Bertoša, Istra: Doba Venecije, Žakan Juri, Pula 1995.

\section{DONATI - SESLER 1750}

Vitalino Donati - Leonard Sesler, Della storia naturale marina dell'Adriatico (intorno ad un nuovo genere di piante terrestri), Appresso Francesco Storti, Venezia 1750.

(http://books.google.hr/books?id=aiSGg2lvhM $k C \& p g=P P 14 \& l p g=P P 14 \& d q=$ dellastoria + natu rale+marina+dell\%27adriatico \&source=bl\&ots =EzM3Fitrr9\&sig=PTJZ4YoAhesjm_DCowjphjU 9TOY\&hl=hr\&sa=X\&ei=11ggT8-gEoq0-QaJ55X EBA\&ved $=0 C H w Q 6 A E w C Q \# v=$ onepage $\& q=r o v$ igno\&f=false) books?id=aiSGg2lvhMkC\&pg=PP $14 \&$ lpg=PP14\&dq=dellastoria + naturale + marin a+dell\%27adriatico\&source=bl\&ots=EzM3Fitrr 9\&sig=PTJZ4YoAhesjm_DCowjphjU9TOY\&hl=hr \&sa $=X \&$ ei=11ggT8-gEoq0-QaJ55XEBA\&ved $=0 \mathrm{C}$

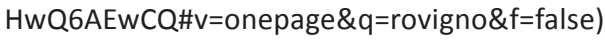
books?id=aiSGg2lvhMkC\&pg=PP14\&lpg=PP14 $\& d q=$ dellastoria + naturale + marina + dell\%27adri atico\&source $=$ bl\&ots $=$ EzM3Fitrr9\&sig=PTJZ4Yo Ahesjm_DCowjphjU9TOY\&hl=hr\&sa=X\&ei=11g gT8-gEoq0-QaJ55XEBA\&ved=0CHwQ6AEwCQ\# $\mathrm{v}=$ onepage $\& \mathrm{q}=$ rovigno $\& \mathrm{f}=\mathrm{false}$ )

\section{GORACUCHI 1863}

J. Alexander Goracuchi (ritter Von.), Die Adria und ihre Küsten mit Betrachtungen über Triest als Badeort nebst einer Erörterung über das Seewasser und dessen heilbringende Wirtung, Buchdruckerei des Oesterreichischen Lloyd, Triest 1863.

\section{HACQUET 2008}

Balthasar Hacquet, Oslikavanje i opisivanje jugozapadnih i istočnih Wenda, Ilira i Slavena, njihove zemljopisne rasprostranjenosti od Jadranskog pa sve do Crnog mora, njihova života i običaja, zanata i obrta, religije, itd., a po povratku s desetogodišnjeg proputovanja i četrdesetogodišnjeg boravka u tim krajevima, Leipzig u industrijskoj obradi, Etnografski Muzej Split, Split 2008.

\section{KEČKEMET 1969}

Duško Kečkemet, "Antički spomenici Pule na slikama i u opisima stranih autora od XV do XIX stoljeća", Jadranski zbornik VII, Rijeka - Pula 1969., str. 549.-590.

\section{KRMPOTIĆ 1997}

Ljudevit Krmpotić, Spon, Adam, Cassas i Lavallée u Hrvatskoj, Nakladni zavod Hrvatski zapisnik, Hannover - Čakovec 1997.

\section{KUDIŠ 1994}

Nina Kudiš, "Tutte le opere d'architettura et 
prospetiva di Sebastiano Serlio (1619) i praksa izrade drvenih oltara u Istri", u: Annales 5/'94, Zgodovinsko društvo za južno Primorsko/ Società storica del Litorale, Koper 1994.

\section{LEVENTAL 1989}

Zdenko Levental, Britanski putnici u našim krajevima, od sredine XV do početka XIX veka, Dečje novine, Gornji Milanovac 1989.

\section{LOVELL 1999}

Lovell Mary S., A rage to live. A biography of Richard and Isabel Burton, Abacus, London 1999.

\section{MONZALI - ŠURAN 2011}

Luciano Monzali - Fulvio Šuran, Istria e Puglia fra Europa e Mediterraneo, Edizioni Studium, Roma 2011.

\section{MULJAČIĆ 1996}

Žarko Muljačić, Putovanja Alberta Fortisa po Hrvatskoj i Sloveniji (1765-1791), Književni krug, Split 1996.

\section{PAVIĆ 2002}

Milorad Pavić, Plovidbene rute srednjim i južnim Jadranom u izolaru Giuseppea Rosaccia, Radovi Zavoda za povijesne znanosti HAZU u Zadru, sv. 45/2003., str. 153.-199.

\section{PEDERIN 1991}

Ivan Pederin, Jadranska Hrvatska u austrijskim i njemačkim putopisima, Nakladni zavod Matice hrvatske, Zagreb 1991.

\section{RUDELIĆ 1977}

Rudelić Ivan, Povijest medicine u južnoj Istri, vlastita naklada, Pula 1977.

\section{VALENTINI 1998}

Corinna Valentini, L'esilio del Leone, Richard F. Burton dall'Africa a Trieste, Mgs Press, Trieste 1998.

\section{YRIARTE 1878}

Charles Yriarte, "Istria y Dalmatia", 1874., u: El mundo en la mano - Viaje pintoresco a las cinco partes del mundo, por los mas celebres viajeros, Montaner y Simon Editores, Barcelona 1878, str. 633.-678.

\section{YRIARTE 1999}

Charles Yriarte, Istria \& Dalmacija: putopis, predgovor Miroslav Bertoša, Vladimira Mirković-Blažević (prev.), Antibarbarus, Zagreb 1999.

\section{ZLODI 2007}

Zdravka Zlodi, Putopis Aleksandra Sapiehe u kontekstu epohe prosvjetiteljstva, Povijesni prilozi, vol. 32., Hrvatski institut za povijest, 2007., str. 183.-207.

\section{RIASSUNTO \\ Viaggiatori europei in Istria daI XV al XIX secolo}

Archivi di stato e parrocchiali, oltre a scritti di vario genere, documenti e manoscritti contribuscono a formare assieme ai racconti di viaggio una base di dati e materiali adatti allo studio della storia sia mondiale sia istriana. L'obiettivo di questo lavoro è un'analisi accurata e profonda della storia della penisola istriana sulla base di una serie di scritti di autori e viaggiatori europei passati per le nostre zone nell'Evo Moderno, più precisamente dal XV al $X X$ sec. Il quadro d'insieme non contiene solo fatti strettamente storici, ma include un'ampia serie di occupazioni e discipline. Nello studio dei vari testi incontriamo fatti etnologici di grande valore tramite cui scopriamo interessanti dati su un dato popolo, del suo destino e delle caratteristiche fisiche. I diversi viaggiatori passavano l'Istria in due giorni, oppure vi si soffermavano per quarant'anni e vi studiavano profondamente alcune caratteristiche specifiche. Viene da sé che simili ricerche approfondite rappresentano sicuramente una fonte più o meno attendibile, mentre impressioni fugaci su carta sarebbero da prendere quantomeno con una leggera dose di scetticismo. 
Nel periodo preso in questione l'Istria non si trovava nelle sue condizioni migliori; i provveditori della Serenissima usavano descrizioni spaventose della situazione in Istria quando inviavano relazioni al governo con lo scopo di ricevere maggiori somme di denaro. La regione è devastata, abbandonata, epidemica ed ammalata; è alla perenne ricerca di una medicina che per secoli le rimarrà irraggiungibile e troppo cara. L'Istria vive due dimensioni parallele; il superbo leone tenta di mozzare le ali all'aquila a due teste, mentre la casata austriaca cerca a sua volta di reprimere il potere del vigoroso avversario. La battaglia si protenderà a lungo poiché nessuno dei due mollerà la presa. Tale difficoltosa situazione, dove il peso sulla bilancia si sposta di continuo, porterà l'innocente popolazione da una guerra all'altra. II quadro, tuttavia, non era così nero; si viveva e si lavorava comunque, si stava in compagnia e si gioiva. Ai matrimoni, in Istria centrale, si ballava, mentre al contempo sulla costa, a luce di candela, nelle varie osterie e "spacci", nascevano le "bitinade" rovignesi.

L'Istria venne percorsa da pittori e artisti, architetti e scultori, storici ed etnologi, naturalisti e oceanografi. I panorami istriani, la natura incontaminata e l'apertura della popolazione alla gentilezza stupì ed affascinò molti. Quest'unico clima "frizzante" e difficile da descrivere è il prodotto di un miscuglio di popoli che abitano gli stessi spazi e che da secoli hanno imparato a convivere. Queste diversità non hanno mai smesso di arricchire questo piccolo territorio a forma di cuore adagiato nel Mar Adriatico. II suo segreto si nasconde, in parte, sotto il lenzuolo dell'apparente selvaggità delle popolazioni che vivevano a metà strada tra l'Est e l'Ovest e che erano governate da grandi potenze, repubbliche e monarchie. Ciascun viaggiatore percepì l'Istria a modo suo, e nessuno di loro vi passò accanto senza lasciare un commento, sia esso negativo o positivo.

Per capire chi siamo non possiamo affidarci solo ad un'opinione personale; dobbiamo ascoltare gli altri con attenzione e pazienza, sentire coloro che ci aiuteranno a scoprire la nostra vera realta'. Gli scrittori di viaggio hanno lasciato delle tracce mettendo su carta le proprie impressioni e hanno avuto il coraggio di solcare l'immaginario occidentale nei riguardi del selvaggio ma vicino Oriente. Soggettivamente parlando possiamo criticarli o lodarli, oggettivamente, invece, ci danno molto spazio per pensare e per ulteriori ricerche.

Parole chiave: memorie di viaggio, Istria, Evo moderno, Oriente, costa croata

\section{SUMMARY}

\section{European Travellers in Istria from the Fifteenth to the Nineteenth Century}

Church and state archives, all kinds of antique documents, records and writings together with travel writers' reports constitute the fundamental corpus for any general study of history, as well as it applies to the history of Istria. This work aims at researching the history of the Istrian peninsula considering a few descriptions regarding this territory, drawn up by passengers coming down from Europe, in Modern Age that is from the fifteenth down to the twentieth century. This work is not merely focused on historical facts, but affects, by its nature, a wider spectrum of disciplines and professions. In analysing various texts we find valuable ethnographical facts giving basic information on people; this evidence speaks of their fate and aspect. Travellers went through in two days, or they stayed as long as forty years and were consecrated to the study of some peculiarities of the province. We can undoubtedly rely on such research ventures, while it would be better to take with scepticism other cursory impressions. 
The Istrian peninsula, in the period taken into account, was surely not in its best glow; Venetian regents used the description of its scary conditions in the reports sent to the central government, when asking for financial aid. The province was devastated, deserted, plundered; for a long time she asked helplessly for an unreachable and too expensive medicine. Istria lived in a dual dimension; the proud lion aims to shorten the wings to the double-headed eagle in the same measure as the Austrian Court tried to annihilate the too powerful rival. This struggle will extend over several centuries since no one of them gave in nor lowered its head. The repercussions of such position, where the weight on the balance is in perpetual change from one arm to the other, drew the population from war to war. The image was not anyway so dark; people lived and worked, socialized and enjoyed. They danced on matrimonies in the inland; at the same time, under candle light in various "osterie" or "spaccios", by the sea, "bitinade" from Rovinj were born.

Istria was visited by painters and artists, architects and sculptors, historians and ethnologists, naturalists and oceanographers. Istrian panoramas, the nature and the warmblood affability of the populace fascinated and captivated a lot of them. This interesting and hard to define "sparkling atmosphere" is given by the mixture of several nations sharing the same space and coexisting on the same territory for centuries. These diversities have never stopped to enrich this small heart-shaped province in the middle of the Mediterranean. Its attractiveness was partly hidden in the savageness of a mid-European mixed people, driven by powerful countries, republics or monarchies, and in the unusual sights and spectacles. Everyone experienced Istria in his own and unique way and no one passed by without leaving a commentary, even if a bad one.

We should not rely just on our thoughts to understand how we really are, but carefully and clearly listen to others who will show us our nature in a more objective way. Travellers left their trace; they noted their impressions and plowed in the Western imaginary furrow of their neighbouring East. Subjectively speaking, we can objurgate or praise s'them, but, objectively, they give us a lot of space for reflection and for further research and study.

Keywords: travel writing, Istria, Modern Age, East, Croatian coast 
